\title{
Returning Separation-of-Powers Analysis to Its Normative Roots: The Constitutionality of Qui Tam Actions and Other Private Suits to Enforce Civil Fines
}

\author{
by Peter M. Shane
}

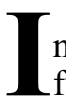
n thoughtful dicta uttered 60 years ago, Justice Frankfurter observed that even a legislature clear as to its regulatory objectives faces hard choices in selecting remedies for the implementation of those objectives:

\begin{abstract}
How to effectuate policy - the adaptation of means to legitimately sought ends - is one of the most intractable of legislative problems. Whether proscribed conduct is to be deterred by qui tam action or triple damages or injunction, or by criminal prosecution, or merely by defense to actions in contract, or by some, or all, of these remedies in combination, is a matter within the legislature's range of choice. Judgment on the deterrent effect of the various weapons in the armory of the law can lay little claim to scientific basis. Such judgment as yet is largely a prophecy based on meager and uninterpreted experience.
\end{abstract}

Justice Frankfurter's list of remedial examples highlights more than just the variety of mechanisms that Congress has available to induce regulatory compliance. His list also reveals the wide range of actors potentially involved in executing those mechanisms. Qui tam actions, which Frankfurter mentions first, are brought by private plaintiffs on behalf of the government. ${ }^{2}$ Civil damages may be sought either by private plaintiffs or by government agencies. Criminal prosecutions are instituted exclusively by government prosecutors, and so on. To say that picking among remedial options is "a matter within the legislature's range of choice" is necessarily to imply that it is likewise a matter of legislative discretion to decide who shall be empowered to pursue remedial action.

In recent years - and quite dramatically over the last decade - the winds of U.S. Supreme Court favor have seemed

The author is Visiting Professor of Law and Public Policy, H. John Heinz III School of Public Policy and Management, Carnegie Mellon University, and Professor of Law, University of Pittsburgh School of Law. The author would like to thank Prof. Gregory P. Magarian of Villanova Law School for his thoughtful comments on an earlier version of this Article.

1. Tigner v. Texas, 310 U.S. 141, 148 (1940) (upholding the constitutionality of Texas antitrust laws).

2.

Qui tam is short for the Latin phrase qui tam pro domino rege quam pro se ipso in hac parte sequitur, which means "who pursues this action on our Lord the King's behalf as well as his own." The phrase dates from at least the time of Blackstone. See 3 W. Blackstone, Commentaries *160.

Vermont Agency of Natural Resources v. United States ex rel. Stevens, 120 S. Ct. 1858, 1860 n.1, 30 ELR 20622, 20622 n.1 (2000). to blow hot and cold over the prospects for two closely related remedial mechanisms. One, exemplified by the Clean Water Act (CWA), ${ }^{3}$ is the "citizen suit" that permits any person aggrieved by a defendant's alleged violation of federal law to enforce federal civil fines against the defendant. The other is qui tam litigation, i.e., civil actions brought by private parties on behalf of the United States to recover fines for the federal treasury and a bounty for the private litigant or "relator." Qui tam litigation is now authorized most importantly by the False Claims Act (FCA), ${ }^{4}$ which provides remedies for fraud against the federal government.

What has sometimes seemed problematic about these remedial mechanisms has not been the kind of pressure they seek to apply in implementing federal law, but rather the parties who are empowered to initiate that pressure. Justice Scalia, often accompanied by one or more of the Court's other conservative voices, has questioned whether such litigation may be squared with the U.S. Constitution's intended allocation of governmental authorities. Because of the supposedly attenuated nature of the private injuries that give rise to such suits, Justice Scalia has repeatedly urged that their resolution goes beyond the judiciary's Article III power to resolve disputes on behalf of persons with proper standing. ${ }^{5}$ Because these suits result in the enforcement of civil fines, he has reserved the question whether they constitute a form of law enforcement that may be constitutionally undertaken only by the federal executive. ${ }^{6}$

Doubts about standing, for a majority of the Court, now appear to be receding. In Vermont Agency of Natural Resources $v$. United States ex rel. Stevens, ${ }^{7}$ the once-doubting Justice Scalia wrote for a unanimous Court in upholding the Article III standing of qui tam plaintiffs. Another recent decision, Friends of the Earth, Inc. v. Laidlaw Environmental

3. 33 U.S.C. $\S 1251-1387$, ELR STAT. FWPCA §§101-607.

4. 31 U.S.C. $\S \S 3729-3733$ (1994).

5. E.g., Lujan v. Defenders of Wildlife, 504 U.S. 555, 22 ELR 20913 (1992) (dismissing Endangered Species Act citizen suit for lack of Article III standing); Friends of the Earth v. Laidlaw Envtl. Servs. (TOC), Inc., 120 S. Ct. 693, 713, 30 ELR 20246, 20252 (2000) (Scalia, J., dissenting) (dissenting from recognition of standing to bring citizen suit action under the CWA). See also Steve France, Qui Tam Pop Quiz, ABA J., Feb. 2000, at 32 (quoting Justice Scalia's skeptical remarks during oral argument in Vermont Agency).

6. Vermont Agency, 120 S. Ct. at 1865 n.8, 30 ELR at 20624 n.8.

7. 120 S. Ct. 1858, 30 ELR 20622 (2000). 
Copyright $(2000$ Environmental Law Institute $®$, Washington, DC. reprinted with permission from ELR®—The Environmental Law Reporter $®$. All rights reserved.

Services (TOC), Inc., ${ }^{8}$ seems to put at rest the Article III issues with regard to citizen suits, as well — at least insofar as the words "at rest" can plausibly be used over Scalia's dissent and in an area of the law as mercurial as standing.

The Article II question, however, lives on. Currently pending is the Fifth Circuit's en banc rehearing in Riley v. St. Luke's Episcopal Hospital, ${ }^{9}$ in which a panel of that court found qui tam actions to constitute an impermissible delegation of the executive branch's law enforcement authority. The majority in Vermont Agency made a point of reserving this very question. ${ }^{10}$ Likewise, while voting to uphold standing in Laidlaw, Justice Kennedy, in a separate concurrence, all but expressly invited future citizen suit defendants to raise an Article II challenge to the CWA. ${ }^{11}$

Notwithstanding these challenges, it is quite likely that, within the next few years, the Court will establish that private suits to enforce civil fines do not offend any separation-of-powers requirement, whether emanating from Article III or from Article II. Indeed, the challenges to such suits would seem all but frivolous, except for one unfortunate development: In a variety of contexts, the Court in recent decades has increasingly taken deployed separation-of-powers doctrines animated by normative understandings of executive and judicial power that are at odds with both histoy and good policy. Judge-made tests of standing have taken on a frustrating life of their own, unmoored to the modest constitutional imperative of limiting federal litigation to genuinely adversarial disputes that call for more than abstract review. Several Justices-Justice Scalia most notably among them-pursue a vision of executive power that goes beyond the constitutional commitment to remove the legislative branch from executive administration to a model of a hermetically sealed executive that is significantly insulated from Congress' express authority to regulate how the departments of government implement law.

In this Article, I seek to accomplish three things. The first is to review and place in context the evolution of standing law since the Court decided Lujan v. Defenders of Wildlife, ${ }^{12}$ a pivotal 1992 opinion that seemed at the time to sound the death knell for a variety of citizen suits. My principal aim is to identify the scope within which the Court now seems to approve Congress' discretion to use citizen suits as a way to deter public law violations. Such approval is consistent with the normative underpinnings of standing law. The second aim is to explain why there is no persuasive Article II-based objection to either citizen suits or qui tam actions. The Court should move beyond its occasional recent fetishism with regard to executive power and recognize that these private suits are wholly consistent with Article II values. The third aim is to urge that the Court reorient its jurisprudence with regard to citizen suits and qui tam actions along the lines of Justice Frankfurter's insight. The Court should acknowledge that private suits to enforce public norms have become a conventional form of federal litigation that need not be further legitimated through assimilation to a private-law model.

\footnotetext{
8. 120 S. Ct. 693, 30 ELR 20246 (2000).

9. 196 F.3d 514 (5th Cir. 1999) (en banc).

10. See Vermont Agency, 120 S. Ct. at 1865 n. 8,30 ELR at 20624 n. 8 .

11. Laidlaw, 120 S. Ct. at 713, 30 ELR at 20252 (Kennedy, J., concurring).

12. 504 U.S. 555, 22 ELR 20913 (1992).
}

\section{Private Standing to Enforce Civil Fines}

\section{Untangling the Roots of Standing Doctrine}

Standing doctrine has become so labyrinthine that it is easy to forget that the concept is rooted in a fairly simple idea. The Court decided early on that the constitutional authority of the federal judiciary to decide various classes of "cases" and "controversies" is not a plenary power to answer any legal question whatever. Specifically, the Court may not decide nonadversarial suits, nor engage in what scholars of judicial review usually call "abstract review." In federal courts, review is impermissibly "abstract" if it entails merely the delivery of advice as to the constitutionality of legislative or executive action, ${ }^{13}$ the prospect of adjudication based on facts too vague and ill-defined for definitive assessment, ${ }^{14}$ or the issuance of orders having no conclusive effect on the legal rights or interests of contending parties. ${ }^{15}$ To conclude that a party has standing with regard to a particular claim is, at root, to decide that, given the nature of a particular claim and a litigant's relationship to the claim presented, the suing party is not advancing a case that is collusive $^{16}$ or merely abstract. ${ }^{17}$

In private suits at common law, this sort of inquiry would seem superfluous. That is because the work of establishing whether a party has a legal right to sue is subsumed in the concept of "cause of action." A plaintiff who possesses a cause of action is entitled to seek judicial intervention in his or her dispute. There is no separate "standing" inquiry whether the plaintiff has a sufficient stake in the outcome of the dispute to render the lawsuit concrete and not abstract. Why the Court has evolved a full-blown standing jurisprudence in public law as a supplement or alternative to cause of action analysis is puzzling - the word "standing" does not appear in the Constitution. Yet, until recent decades, the Court at least discussed standing in terms that could be rendered comprehensible as an effort to import "cause of action" thinking into public litigation. ${ }^{18}$

13. See Gerald Gunther \& Kathleen M. Sullivan, ConstituTIONAL LAW 28 (13th ed. 1997) (discussing Court's refusal to provide President Washington legal advice in 1793 concerning "some legal questions involving America's neutrality toward the ongoing war between England and France.").

14. 1 Laurence H. Tribe, American Constitutional Law 328-32, 388 (3d ed. 2000).

15. Hayburn's Case, 2 U.S. (2 Dall.) 408, 410 n.(a) (1792) (quoting opinion of the U.S. Circuit Court for the District of New York that federal judges could not constitutionally perform the nonjudicial functions delegated to them under a statute authorizing judges to determine amounts of Revolutionary War pensions, subject to review by the Secretary of War).

16. For early examples of the Court's condemnation of collusive suits, see United States v. Veazie, 49 U.S. (8 How.) 251 (1850) and Cleveland v. Chamberlain, 66 U.S. (1 Black) 419 (1861).

17.

A federal court cannot "pronounce any statute, either of a state or of the United States, void, because irreconcilable with the constitution, except as it is called upon to adjudge the legal rights of litigants in actual controversies." Have the appellants alleged such a personal stake in the outcome of the controversy as to assure that concrete adverseness which sharpens the presentation of issues upon which the court so largely depends for illumination of difficult constitutional questions? This is the gist of the question of standing.

Baker v. Carr, 369 U.S. 186, 204 (1962)

18. On the Court's efforts generally to fit public law litigation to a private-law mold, see Jerry L. Mashaw et AL., Administrative Law: The American Public Law System 744-47 (4th ed. 1998). 
Copyright $@ 2000$ Environmental Law Institute $®$, Washington, DC. reprinted with permission from ELRß—The Environmental Law Reporter®. All rights reserved.

Flast v. Cohen $^{19}$ is a perfect example. In this case, the Court decided that taxpayers had standing to challenge federal expenditures in support of parochial education as a potential violation of the Establishment Clause. The Court confronted this question against the backdrop of an earlier decision, Frothingham v. Mellon, ${ }^{20}$ which held that a taxpayer did not have standing to challenge federal spending in support of maternal health programs as a potential violation of the Tenth Amendment. In Flast, the Court prefaced its standing analysis as follows:

The question whether a particular person is a proper party to maintain the action does not, by its own force, raise separation of powers problems related to improper judicial interference in areas committed to other branches of the Federal Government. ... [I]n terms of Article III limitations on federal court jurisdiction, the question of standing is related only to whether the dispute sought to be adjudicated will be presented in an adversary context and in a form historically viewed as capable of judicial resolution. $^{21}$

Whether a taxpayer suit met this standard - that is, whether it amounted to litigation "in a form historically viewed as capable of judicial resolution"-depended, the Court continued, on a two-part inquiry:

First, the taxpayer must establish a logical link between that status and the type of legislative enactment attacked. Thus, a taxpayer will be a proper party to allege the unconstitutionality only of exercises of congressional power under the taxing and spending clause of Art. I, §8, of the Constitution. It will not be sufficient to allege an incidental expenditure of tax funds in the administration of an essentially regulatory statute. ... Secondly, the taxpayer must establish a nexus between that status and the precise nature of the constitutional infringement alleged. Under this requirement, the taxpayer must show that the challenged enactment exceeds specific constitutional limitations imposed upon the exercise of the congressional taxing and spending power and not simply that the enactment is generally beyond the powers delegated to Congress by Art. I, $\S 8$. When both nexuses are established, the litigant will have shown a taxpayer's stake in the outcome of the controversy and will be a proper and appropriate party to invoke a federal court's jurisdiction. $^{22}$

After Flast, federal taxpayers thus had standing to challenge national tax and spending programs, but not regulatory programs, and to do so under only the Establishment Clause and such other constitutional constraints as the Court might deem "specific" limits on taxing and spending.

This formulation at first is all but impenetrable. The plaintiff's first required showing is that the challenged legislation is an exercise of congressional power under the Constitution's Taxing and Spending Clause, ${ }^{23}$ and not an application of some other regulatory power that the Constitution confers on the legislative branch. In terms of standing, however, it is mysterious why it would be "logical" to permit taxpayers to challenge alleged violations of the Taxing and Spending Clause, but not to challenge impermissible spend-

19. 392 U.S. 83 (1968).

20. 262 U.S. 447 (1923).

21. Flast, 392 U.S. at 100-01 (emphasis added).

22. Id. at 102-03.

23. U.S. ConST. art. I, §9, par. 7. ing incidental to the implementation of some other clause. This distinction is simply irrelevant to whether the case at hand is being "presented in an adversary context and in a form historically viewed as capable of judicial resolution."

The second required showing, that "the challenged enactment [allegedly] exceed [. . .] specific constitutional limitations imposed upon the exercise of the congressional taxing and spending power," is equally obscure. Comparing Flast with Frothingham, it appears that the Court deems the Establishment Clause, but not the Tenth Amendment, to be a "specific" limitation on taxing and spending powers. But why? Neither clause mentions either taxing or spending. Moreover, once again, the choice of clause under which to sue is unconnected to what the Flast Court said was the sole constitutional issue with regard to standing, namely, whether the case at hand is being "presented in an adversary context and in a form historically viewed as capable of judicial resolution."

The Flast two-part test is far more easily understood if translated into "cause of action" terms: The Court is essentially interpreting the Constitution as implying a right of action under the Establishment Clause for taxpayers to challenge direct exercises of Congress' taxing and spending powers. This would be a sensible inference by the Court because, without the prospect of judicial enforcement, the Establishment Clause would be substantially eviscerated. If taxpayers could not challenge spending in support of religion, there would likely be no other specially affected plaintiffs to present the dispute in a yet more concrete form. Spending cases, unlike cases of regulatory action, are unlikely to target particular parties for adverse action in a way that would ensure a special immediacy to their complaints about unconstitutional action. Moreover, the structural case for judicial enforcement of the First Amendment - namely, that First Amendment rights are likely to have special salience for individual persons systematically underprotected by ordinary political processes - distinguishes the First Amendment from the Tenth Amendment. For these reasons, it is reasonable to conclude that a taxpayer making a Flast-type claim has standing because, under the Constitution, he or she has an implicit cause of action. Indeed, an opinion written in these terms would have been far more straightforward than Flast.

Applying cause of action analysis in public law perhaps became muddied because of the notorious ambiguity in the cause of action concept. It is easy to slip from speaking of "cause of action" as a legal right to sue, to speaking of "cause of action" as a meritorious claim. For example, in a variety of administrative lawsuits in the 1920s and 1930s, the Court rejected various parties' standing to sue on the ground that they had not demonstrated that they had suffered a "legal wrong," or conversely, the violation of a "legal right," as a prerequisite to suit. ${ }^{24}$ This inquiry, however, seemed to reach the merits as part of the preliminary inquiry into standing and to have nothing to do with the imperative to avoid abstract litigation, the command that undergirds standing jurisprudence.

The Court began to work its way out of this conundrum in 1940. In Federal Communications Commission v. Sanders Bros., ${ }^{25}$ the Court confronted a challenge to a Federal Com-

24. Mashaw et AL., supra note 18, at 950-57.

25. 309 U.S. 470 (1940). 
Copyright $@ 2000$ Environmental Law Institute $®$, Washington, DC. reprinted with permission from ELR®—The Environmental Law Reporter $®$. All rights reserved.

munications Commission (FCC) licensing decision that had been filed by the FCC licensee's economic competitor. By relying on the express terms of the Federal Communications Act, ${ }^{26}$ the Court was able to separate clearly the merits of the claim from the threshold issue of a competitor's right to sue. That Act explicitly authorizes suit by "any ... person aggrieved or whose interests are adversely affected by any decision of the Commission granting or refusing" a license. ${ }^{27}$ Reading this language literally, the Court had no problem concluding that Congress had conferred on licensees' economic competitors a legal right to sue to challenge FCC licensing decisions. It seemed obvious enough that making a licensee better off "adversely affects" the licensee's economic competitors. The Court entertained no doubt that Congress could confer "standing" on economic competitors and, relying on the statute, the Court was able to resolve the standing issue without regard to whether the plaintiff had suffered a "legal wrong."

Sanders Bros. could not provide a comprehensive framework for public litigation, however, for two obvious reasons. It did not address the question of implied rights of action under the Constitution. And it did not provide a rubric for dealing with standing under the majority of administrative statutes that are silent on anyone's legal right to sue. How to handle such statutes is a question of genuine day-to-day importance in the life of administrative agencies, but not a question squarely addressed by the Court for another 30 years.

In Association of Data Processing Organizations (ADAPSO) v. Camp, ${ }^{28}$ the Supreme Court in 1970 considered a challenge by non-bank sellers of data processing services to a decision by the Comptroller of the Currency to permit national banks to enter the data processing services market. The gravamen of the suit was obviously similar to the complaint made in Sanders Bros. However, unlike the Federal Communications Act, the statutes that underlay ADAPSO were silent on the question of standing to sue. ${ }^{29}$ The petitioners were thus open to the argument that they lacked standing because, under the pre-Sanders Bros. cases, they lacked a "legal interest" in being free of economic competition by the banks.

The Court, however, rejected this analysis. It emphatically separated the "legal interest" test, as going to the merits of the case, from the threshold question of standing. ${ }^{30}$ The Court then proceeded to approach its standing analysis through three analytically distinct questions that it unfortunately blurred: First, were petitioners required to demonstrate that they had been injured by the Comptroller's decision in order to have a legal right to sue under the Administrative Procedure Act (APA) ? ${ }^{31}$ Second, did the National Banking Acts support their cause of action? Finally, was there any constitutional barrier to the petitioner's standing to sue?

According to the Court, "[t]he first question," relevant to standing in ADAPSO, is "whether the plaintiff alleges that

26. 47 U.S.C. $\$ 151$ et seq.

27. Id. §402(b) (1934), as amended, id. §402(b)(8) (1994).

28. 397 U.S. 150 (1970).

29. Bank Service Corporation Act of 1962, 12 U.S.C. $\$ 1864$; National Bank Act, 12 U.S.C. \$21 et seq.

30. ADAPSO, 397 U.S. at 153.

31. 5 U.S.C. \$702, available in ELR Stat. Admin. Proc. the challenged action has caused him injury-in-fact, economic or otherwise." 32 The placement of this paragraph, coming just after a statement regarding the constitutional basis for Flast, ${ }^{33}$ creates the possible impression that this "first question" regarding actual injury to the party asserting standing must be addressed because of Article III considerations. The only reason, however, why injury was critical to $A D A P S O$ was a statutory one. Because the administrative statutes specifically at issue did not themselves give the petitioners a legal right to sue, the complainants had to rely on the APA. The APA provides: "A person suffering legal wrong because of agency action, or adversely affected or aggrieved by agency action within the meaning of a relevant statute, is entitled to judicial review thereof." 34 In other words, Congress, through the APA, gave standing to two classes of plaintiffs who could not rely on the specific terms of other administrative statutes: plaintiffs suffering "legal wrong," and plaintiffs "affected or aggrieved by agency action within the meaning of a relevant statute." Because the ADAPSO complainants had not suffered "legal wrong," they had to show themselves "affected or aggrieved" by the agency action they challenged. Although the language of the APA is typically overlooked in discussions of standing, it is solely because of this statutory requirement that the fact of injury was important to a standing analysis in $A D A P S O$.

The second question is whether the relevant banking statutes supported the ADAPSO complainants' cause of action. If the National Banking Act, the Bank Service Act of 1962, or the APA itself had conveyed a right to sue in terms identical to the Federal Communications Act, this question would have turned entirely on the existence of injury-in-fact. Under Federal Communications Act-type language, all the complainants would have had to show is that they were "adversely affected or aggrieved." But no such provision appears in the National Banking Act. The APA, on which the ADAPSO complainants exclusively relied, does not categorically confer standing on all persons "adversely affected or aggrieved by agency action." In order to have standing under the APA, a plaintiff must be "adversely affected or aggrieved by agency action within the meaning of a relevant statute." 35

It is the italicized phrase that the Court had to interpret in ASAPSO. One way, of course, that plaintiffs could be aggrieved by agency action "within the meaning of a relevant statute" would be to establish that they had suffered a "legal wrong." But plaintiffs suffering a "legal wrong" already have a right to sue under the APA through an earlier phrase in the same sentence. Thus, to be "adversely affected or aggrieved" must mean something different from having suffered a legal wrong. Seeking to avoid a reading of the italicized words that would redundantly impose the "legal wrong" test, the $A D A P S O$ Court supplied a new method for discerning the existence of an implicit cause of action under the APA. In order to be adversely affected "within the meaning of a relevant statute," the Court indicated that a plaintiff would have to show that "the interest sought to be protected by the complainant is arguably within the zone of interests to

32. ADAPSO, 397 U.S. at 152.

33. Id. at 151-52.

34. 5 U.S.C. \$702, available in ELR Stat. Admin. Proc.

35. Id. (emphasis added). 
Copyright $(2000$ Environmental Law Institute $®$, Washington, DC. reprinted with permission from ELRß—The Environmental Law Reporter $®$. All rights reserved.

be protected by the statute ... . in question." ${ }^{36}$ Following $A D A P S O$, it is this "zone of interests" test that, in combination with the injury requirement, is now used to discern parties who have rights of action for declaratory or injunctive relief when an agency acts pursuant to some administrative statute that does not explicitly confer rights to sue.

The third question is whether the $A D A P S O$ petitioners had Article III standing to sue. On this point, the Court reiterated the view of Flast that "the question of standing is related only to whether the dispute sought to be adjudicated will be presented in an adversary context and in a form historically viewed as capable of judicial resolution."37 The $A D A P S O$ petitioners plainly met this standard because their suit was obviously adversarial and not abstract. But-and this "but" is large - the discussion of Article III contiguous with the Court's discussion of the petitioners' injury could again easily be read to imply that the petitioners' showing of injury had been necessary not only to satisfy the APA, but also to render the $A D A P S O$ case "in a form historically viewed as capable of judicial resolution," and thus within the Court's Article III powers. On this reading, a plaintiff's allegation of injury would be a constitutional prerequisite to standing, which Congress could not abridge.

This reading would be unfortunate because it is plainly wrong. As Cass Sunstein has shown at length, injury is not an historically compelled ingredient of federal lawsuits. ${ }^{38}$ "Stranger" lawsuits - suits brought on behalf of noninjured parties to challenge alleged illegality — were clearly viewed as appropriate for judicial resolution in the late 18th century: "Before and at the time of the framing, the English practice was to allow strangers to have standing in many cases involving the ancient prerogative writs," including certiorari, prohibition, and the writ most resembling modern administrative review, mandamus. ${ }^{39}$ These writs were available even to citizens who could not demonstrate a concrete personal interest in a suit's outcome, although relief in such cases was deemed discretionary. ${ }^{40}$ Likewise, English law permitted informers' actions, in which strangers who successfully challenged unlawful conduct were awarded bounties, and relator actions, much like informers' actions, but prosecuted in the name of the Attorney General. ${ }^{41}$

Early state and federal practice confirm the justiciability of "stranger" suits. Sunstein cites a number of early state cases building directly on English practice. ${ }^{42}$ The late Louis Jaffe summarized his own historical summary with the conclusion that "the public action - an action brought by a private person primarily to vindicate the public interest in the enforcement of public obligations - has long been a feature of our English and American law." Congress' frequent early authorization of qui tam litigation - authorizing citizens without any other private stake in a matter to help in the enforcement of federal law-occurred

36. ADAPSO, 397 U.S. at 153.

37. Id. at 151-52.

38. Cass R. Sunstein, What's Standing After Lujan? Of Citizen Suits, "Injuries," and Article III, 91 Mich. L. Rev. 163, 170-78 (1992).

39. Id. at 171 .

40. Id.

41. Id. at 172 .

42. Id. at 173 .

43. Louis L. Jaffe, Standing to Secure Judicial Review: Private Actions, 75 Harv. L. Rev. 255, 302 (1961). in 23 statutes enacted by the first four Congresses. ${ }^{44}$ Early Congresses likewise authorized informers' actions against both public officials and private-law violators. ${ }^{45}$ As Sunstein points out, none of these developments evoked an inkling of contemporaneous protest that private suits by noninjured parties raised constitutional doubts, so long as they were supported by common-law writs or statutory authorization. ${ }^{46}$ In light of this background, the existence of injury personal to a complainant cannot persuasively be viewed, as a historical matter, as an element that determines whether a suit is a permissible case or controversy or an impermissible suit for abstract review. Stranger suits to recover private bounties or public fines or to command official action via mandamus, prohibition, or certiorari were all established forms of action.

This does not mean that courts can ignore the presence of injury altogether in ascertaining whether a plaintiff has a legal right to sue. Under statutes that confer a right to sue only on injured parties, courts obviously must require that plaintiffs plead injury. Moreover, under Article III, the presence of injury may be a strong indication of the nonabstract quality of the suit that renders it appropriate for judicial resolution. But "injury" itself is not what Article III requires; Article III requires only that the plaintiff have a sufficient stake in the outcome of the controversy to render it nonabstract. Congress can confer such a stake by creating statutory interests that go beyond common-law rights, including a bounty for private litigants who are successful in helping to assure legal compliance by others. There is no independent injury requirement that emanates from Article III, properly interpreted.

\section{The Erratic Jurisprudence of Injury}

In emphasizing the element of injury in $A D A P S O$, the Court undoubtedly intended to promote the expansiveness of standing under the APA. With apparent approval, the Court noted: "Where statutes are concerned, the trend is toward enlargement of the class of people who may challenge administrative action. The whole drive for enlarging the category of aggrieved 'persons' is symptomatic of that trend."47 Seen in this light, the Court's original stress on injury-in-fact was designed to enlarge APA standing by highlighting that the standing inquiry was not to be wedded to the merits of the plaintiff's case.

Three ensuing cases on injury and standing decided between 1970 and 1982 seemed to underscore this intended expansiveness. In Sierra Club v. Morton, ${ }^{48}$ the Court dismissed an association's environmental suit because the Sierra Club neglected to plead injury either to the association or its members. The Court made clear, however, that, in redrafting its complaint, the Sierra Club need not plead a monetizable harm in order to qualify as "adversely affected' or 'aggrieved' within the meaning of the APA." The Court reiterated dicta from $A D A P S O$ indicating that "the in-

44. Supplementary Brief for Respondent at 7 n.3, Vermont Agency of Natural Resources v. United States ex rel. Stevens, 120 S. Ct. 1858, 30 ELR 20622 (2000) (No. 98-1828) (1999 WL 1276923).

45. Sunstein, supra note 38 , at 175.

46. Id. at $175-76$.

47. ADAPSO, 397 U.S. at 154.

48. 405 U.S. 727, 2 ELR 20192 (1972). 
Copyright (c) 2000 Environmental Law Institute $₫$, Washington, DC. reprinted with permission from ELR@—The Environmental Law Reporter®. All rights reserved.

terest alleged to have been injured 'may reflect aesthetic, conservational, and recreational,' as well as economic values."49 "Injury," it was evident, was to be considered in broad terms.

In Duke Power Co. v. Carolina Environmental Study Group, ${ }^{50}$ the Court went further and held that, so long as a defendant's conduct threatens to be a "but/for cause" of an injury-in-fact to the plaintiff, it does not matter for standing purposes whether the alleged injury actually provides the gravamen of the plaintiff's legal claim. The Court in Duke Power upheld an environmental group's standing to challenge the issuance of construction permits for two nuclear power plants. The Carolina Environmental Study Group (CESG) contended that a federal statutory limitation on the plants' liability in the event of a nuclear accident would result in an impermissible taking of its members' property should a catastrophic mishap occur. The Court determined that the CESG had asserted a sufficiently concrete threat of harm to support standing, but not because the group or its members were "adversely affected" by the prospect of uncompensated harm at some unspecified future time. Instead, it sufficed for the CESG to allege that plant construction would result in the thermal pollution of lakes that its members used for recreation and that, without the disputed statutory limit on plant liability, financing for plant construction would become unavailable, and the plants would not be licensed or built. $^{51}$ On this analysis, the challenged statute was a but/for cause of the imminent plant construction and resulting thermal pollution. The fact that the thermal pollution would not itself be the consequence of an unlawful act did not mean that the threat of such pollution was an inappropriate basis for standing.

In the furthest-reaching of the post- $A D A P S O$ cases, the Court made clear that Congress could create statutory rights of action based on "injuries" that would not exist absent the statute itself. In Havens Realty Corp. v. Coleman, ${ }^{52}$ a challenge to alleged racial steering by a defendant real estate agency, the Court upheld the standing of a nonprofit fair housing group (HOME) and black and white "testers" hired by the group to investigate the agency's marketing practices. The agency defended on the ground that none of the plaintiffs had been injured; the black "tester" was not a bona fide home buyer, and the white "tester" received accurate market information. The Court concluded otherwise. The white tester could plausibly complain based on his reduced opportunity to live in an integrated neighborhood. ${ }^{53} \mathrm{HOME}$ was injured because the realtor's unlawful acts made it more burdensome for HOME to fulfill its organizational goal of directing its clients toward genuine housing opportunities. ${ }^{54}$ And, under perhaps the most important holding, the black "tester" could sue because the denial to him of accurate information was a cognizable injury because Congress had created a statutory right to truthful information under the Fair Housing Act of $1968 .^{55}$ The use to which he might or might not put the information was irrelevant to the issue of standing.

49. Id. at 738, 2 ELR at 20195 (quoting ADAPSO, 397 U.S. at 154).

50. 438 U.S. 59, 8 ELR 20545 (1978).

51. Id. at 73-74, 8 ELR at 20548.

52. 455 U.S. 363 (1982).

53. Id. at $375-78$.

54. Id. at 379 .

55. Id. at 373-74.
Read together, these cases strongly suggest that the injury requirement is a low bar to jump, and, further, that the requirement is to be implemented in accord with the scope of Congress' intent to confer standing. ${ }^{56}$ If this were the Court's consistent approach, then the confusion of standing with "cause of action" and the conflating of statutory and constitutional requirements to plead injury would make little practical difference in the lives of most litigants. Unfortunately, the cases are not consistent in these respects. An especially unsatisfying counterexample is United States v. Richardson, ${ }^{57}$ in which the Court concluded that a voter lacked standing to challenge, under the Constitution's Statement and Accounts Clause, ${ }^{58}$ Congress' persistent practice of not publishing the budgets for U.S. intelligence agencies. The plaintiff argued, with obvious plausibility, that he was significantly burdened in casting an intelligent vote in legislative elections if he could not assess what his representatives had actually done with regard to funding intelligence activities. The Court did not deny that compelled political ignorance was an injury, but it insisted that the injury was too widespread to support standing. ${ }^{59}$ Because the plaintiff's injury supposedly situated him identically to all other voters, the Court concluded that he had stated merely a "generalized grievance," 60 which, if deserving of resolution, could be addressed effectively at the polls.

This treatment of the injury requirement plainly conflates standing with cause of action. Not only is there no obvious constitutional reason for insisting on the relative uniqueness of an alleged injury as a prerequisite to litigation, but it is not even true that Richardson was situated similarly to all other voters. He was situated identically only to those voters for whom a representative's vote on intelligence agency budgeting would be a potentially decisive factor in deciding how to cast the citizen's ballot in the next election. This presumably is not everyone. (By way of comparison, no one has argued that cigarette smokers lack standing to sue tobacco companies, although, for all we know, the health risk posed by smoking may be more widespread than the salience of intelligence agency funding as an issue among voters.) In any event, the pervasiveness of injury seems all but irrelevant to the core concern of standing doctrine that the Court avoid abstract review. If the information plaintiff seeks is genuinely relevant to how he votes, then he would seem to have a stake in seeking that information sufficient to render his dispute nonabstract.

A cause of action analysis in Richardson would have made more sense. The Court might have concluded that there were insufficient grounds to imply a cause of action directly from the Constitution to enforce what might be construed to be a matter of government management (although it is easy enough to imagine a strong counterargument). This would leave open the question of whether Congress could confer by statute a right to sue to demand federal fiscal infor-

56. $C f$. Public Citizen v. Department of Justice, 491 U.S. 440, 449, 450 (1989) (underscoring breadth of standing under Federal Advisory Committee Act and Freedom of Information Act).

57. 418 U.S. 166 (1974).

58. U.S. Const. art. I, §9, para. 6.

59. Richardson, 418 U.S. at 176-77.

60. Id. at 176 . 
mation - a prospect which, however unlikely, would appear to be entirely constitutional. ${ }^{61}$

The Court further complicated matters through cases in the 1970s and 1980s that not only substituted a standing analysis for a more suitable cause of action analysis, but elaborated two additional standing prerequisites that seem even more plainly merits-related than the injury requirement itself. One has come to be known as the "causality" requirement - there must be a causal link between the challenged conduct of the defendant and the injury that forms the basis of the complaint. ${ }^{62}$ The other is typically called the "redressability" requirement - the injury alleged must be one that is susceptible to redress through the judicial remedy plaintiff is seeking. ${ }^{63}$

It is more than a little peculiar to regard causality and redressability as ingredients of standing. If defendant $B$ has caused no harm to plaintiff $\mathrm{A}$, it would be common understanding that $A$ has no cause of action against $B$ to challenge B's conduct. Likewise, if B has harmed A, but the remedy X that A seeks is irrelevant to that harm, then, once again, the conventional description of the situation would be that A has no cause of action to pursue $X$ against $A$. In either of these circumstances, the suit of A against B would still be "presented in an adversary context and in a form historically viewed as capable of judicial resolution." A's problem would not be an absence of standing, but the certainty that judicial resolution of its complaint will inevitably favor the defendant. ${ }^{64}$

Several cases, each of which could easily have been resolved on cause of action grounds exacerbate this confusion. In Linda R.S. v. Richard D. ${ }^{65}$ the Court denied standing to the mother of an out-of-wedlock child to challenge a district attorney's decision not to prosecute the child's biological father for failure to pay child support. She was held to lack standing because it was too speculative whether the relief she sought would result in the father's actual payment of his support obligations. ${ }^{66}$ Assuming that this is the correct judgment, it would surely have been more straightforward to address the problem presented in terms of rights of action. Criminal prosecutions enjoy a "special status"67 in the American judicial system, and courts would pose obvious risks to due process if they began to supervise not only the conduct of criminal trials, but also the charging decisions that result in those trials. For these reasons, it would be sensible to find that there is no private right of action - at least without explicit legislative authority - to compel a criminal

61. The Court's assertion as to the universality of injury was more plausibly invoked in Schlesinger v. Reservists to End the War, 418 U.S. 208 (1974), a lawsuit challenging the membership of certain federal legislators in the U.S. military reserves, agencies of the executive branch, in alleged violation of the Constitution's Incompatibility Clause, which prohibits simultaneous membership in both elected branches of government, U.S. Const. art. I, §6, para. 2. Even in Schlesinger, however, the alleged injury was arguably greater for those citizens most likely to be affected adversely by the predictably greater or lesser military enthusiasms of those legislators who were also members of the reserve armed services. And, most to the point, the case is also eminently resolvable in cause of action terms.

62. Simon v. Eastern Ky. Welfare Rights Org., 426 U.S. 26, 41-42 (1976). See infra notes 68-69 and accompanying text.

63. Simon, 426 U.S. at 43-46.

64. Mashaw ET AL., supra note 18, at 992.

65. 410 U.S. 614 (1973).

66. Id. at 618 .

67. Id. at 619 . prosecution, which is a public, rather than a private remedy for unlawful behavior. In contrast, the Court's actual rationale - that the connection between criminal sanctions and the inducement of lawful conduct is too speculative to support standing - seems to call into question why we have criminal law at all.

In a similarly confusing way, the Court has used its new standing requirements to prevent a complaining party from demanding more aggressive government action to increase yet another party's tax liability. In Simon v. Eastern Kentucky Welfare Rights Organization, ${ }^{68}$ the plaintiff organization, representing indigent clients, challenged an Internal Revenue Service (IRS) ruling that would relax the requirements to provide emergency room care to poor people that the IRS had previously imposed as a prerequisite for a hospital to enjoy the favorable tax treatment that accompanies status as a charitable institution. The Court denied standing to the plaintiffs on the ground that, even if the emergency care requirements remained in place, it was too speculative whether the hospitals serving the plaintiffs would continue to provide such care or whether they would give up their charitable tax status in order to avoid costly regulatory burdens. ${ }^{69}$ In Allen v. Wright ${ }^{70}$ black parents of school-aged children in Mississippi challenged allegedly unaggressive IRS enforcement of the ban on racial segregation by private schools enjoying charitable institution status for tax purposes. If such status were reliably denied to racially discriminatory private schools, plaintiffs argued, the schools would either have to stop discriminating or raise their tuition. Either response would make them less likely to attract white parents who were currently removing their children from the public schools, and the result would be a greater probability of a racially integrated public school education for the plaintiffs' children. As in Simon, the Court found the prospect of redress too speculative to support standing. The majority concluded that, because integration-resistant white parents might still choose to avoid a desegregated school system, it was too uncertain whether the relief sought by plaintiffs would redress the injury they alleged. ${ }^{71}$

As a substantive matter, the results in Simon and Allen might well be defensible. Absent a contrary statute, it makes sense that the government does not owe a personal duty to citizen A to police the tax liability of citizen B in order to make sure that B fulfills its own distinct legal obligations to A. ${ }^{72}$ This is, however, a conclusion about causes of action, not standing. As written, Simon and Allen imply that even Congress could not constitutionally grant standing to sue to parties situated similarly to the plaintiffs in those cases. Yet, in constitutional terms, this makes no sense. Congress might well be persuaded, when it conditions favorable tax treatment on a taxpayer's voluntary undertaking of certain public obligations, that a helpful way of enforcing those obligations would be to grant putative beneficiaries the right to sue should the government be lax in its enforcement efforts. What the complainants lacked in Simon and Allen was not an adversarial dispute presented in a form historically

68. 426 U.S. 26 (1976).

69. Id. at $42-43$.

70. 468 U.S. 737 (1984).

71. Id. at 758 .

72. This is, for example, the rule in England. See, e.g., Inland Revenue Comm'rs v. National Fed'n of Self-Employed \& Small Businesses, 1982 App. Cas. 617. 
Copyright $(2000$ Environmental Law Institute $®$, Washington, DC. reprinted with permission from ELR®—The Environmental Law Reporter $®$. All rights reserved.

viewed as capable of judicial resolution. What they lacked was a cause of action. ${ }^{73}$

There is an additionally unfortunate aspect of Simon and Allen. Cases such as these, which seek forward-looking injunctive relief, necessarily involve what might be called "remedial hypotheses," that is, some implied narrative with regard to the precise train of events that will enable the relief sought, if granted, to remedy the harms allegedly inflicted on the plaintiff. When the Court finds that a plaintiff has alleged sufficient "redressability" to support standing, it is concluding, in essence, that the remedial hypothesis underlying the complaint is reasonable enough for adjudication to proceed. Yet, following Simon and Allen, the Court has been conspicuously unpredictable in judging the sufficiency of complainants' remedial hypotheses. For example, in Japan Whaling Ass'n v. American Cetacean Society, ${ }^{74}$ the Court upheld the standing of environmental groups to challenge the U.S. Department of Commerce failure to pursue sanctions against Japan for excessive whaling. The Court implicitly assumed that, if the Secretary of Commerce were to proceed against Japan, Japan would cut back on its whaling, thus creating more whale-watching opportunities for the plaintiff groups and their members. ${ }^{5}$ But why this remedial hypothesis is less speculative than Simon and Allen goes unaddressed. Similarly, in Wyoming v. Oklahoma ${ }^{76}$ the Court permitted Wyoming to challenge an Oklahoma law that required Oklahoma power plants to burn mixtures of coal containing at least $10 \%$ coal mined in Oklahoma. Wyoming's remedial hypothesis was that the invalidation of this statute would promote coal sales in Wyoming, which would, in turn, increase severance tax revenues for the state. The fact that Oklahoma power plants could have replaced their Oklahoma coal with coal from states other than Wyoming did not render this hypothesis too speculative in light of evidence that coal-fired plants within Oklahoma had burned Wyoming coal exclusively prior to the enactment of the challenged statute. ${ }^{77}$

It is against this background that the Court, in 1992, most aggressively applied the injury requirement and its newly discovered kin, causality and redressability, to defeat standing for the citizen suits brought in Defenders of Wildlife. ${ }^{78}$ The case involved enforcement of the Endangered Species Act (ESA) ${ }^{79}$ a statute intended to protect aggressively those

73. In other important decisions, the Court made clear its intent to use the injury requirement to block lawsuits aimed at challenging alleged patterns of systemic administrative abuse. City of Los Angeles v. Lyons, 461 U.S. 95 (1983) (plaintiff's status as a victim of police chokehold supports standing in suit for damages, but not for injunctive relief against future uses of excessive force); Lujan v. National Wildlife Fed'n, 497 U.S. 871, 20 ELR 20962 (1990) (refusing to treat alleged administrative pattern of reviewing public lands to be returned to mining activities as a single "final agency action" that could be subjected to judicial review as a whole).

74. 478 U.S. 221, 16 ELR 20742 (1986).

75. Id. at 230 n.4, 16 ELR at 20744 n.4.

76. 502 U.S. 437 (1992).

77. Id. at $447-48 \&$ n.9. It is possible to bring some order to the cases by paying attention to those in which standing was challenged on the pleadings, as opposed to those decided on motions for summary judgment. In the former cases, courts are constrained to accept even tenuous pleadings as true. Yet, the elaboration of a standing jurisprudence that makes its key elements litigable at virtually every stage of a lawsuit would itself seem in tension with the ADAPSO goal of making standing more expansive.

78. 504 U.S. at 555, 22 ELR at 20913.

79. 16 U.S.C. $\S \S 1531-1544$, ELR STAT. ESA §§2-18. species of animals whose continuing existence is threatened by human activity. The Secretary of the Interior is required to identify endangered species and their critical habitat. Federal agencies are required to consult with the Secretary to ensure that actions "authorized, funded, or carried out" by such agencies are not likely to threaten endangered species or their habitat. In 1978, two services within the U.S. Department of the Interior (DOI) - the U.S. Fish and Wildlife Service (FWS) and the National Marine Fisheries Service-promulgated a regulation extending the consultation requirement to agency projects undertaken in foreign nations. The Defenders of Wildlife litigation arose after the DOI in 1983 proposed to revoke this rule and to limit the consultation obligations of federal agencies to those projects undertaken within the United States or on the high seas.

One indication of Congress' intended ambition with regard to ESA enforcement is the generosity with which the ESA describes the legal right to sue to enforce its provisions. The Act provides: "Any person may commence a civil suit on his own behalf (A) to enjoin any person, including the United States and any other governmental instrumentality or agency ... who is alleged to be in violation of any provision of this chapter. . . ."80 Quite sensibly, the court of appeals read this provision as creating a cause of action in any person to enforce a procedural right under the statute, namely, a right to the interagency consultation that the statute demands. ${ }^{81}$ The Court, in a majority opinion written by Justice Scalia, rejected this analysis. The Court held that the terms of the ESA "citizen suit" authority did not obviate the requirement for plaintiffs to allege sufficiently concrete and particularized injuries to meet Article III standing requirements. ${ }^{82}$ Without such allegations, the Court indicated, a citizen complaint would allege no more than the kind of generalized grievance that is too abstract to support judicial review. ${ }^{83}$

Anticipating this analysis, Defenders of Wildlife had made injury claims on behalf of certain of its members. Two members offered affidavits that they had previously traveled abroad to observe endangered species at what were currently sites of USAID-funded foreign projects, and that the continuance of these projects without DOI consultation would make it less likely that such species would be available for observation on future trips that the affiants hoped to take.

The majority, however, rejected these allegations as insufficient to support standing. The affidavits did not indicate in a specific way that the members were users of specific areas endangered by challenged activity. ${ }^{84}$ Nor did the members allege any concrete interest in the specific subpopulations of endangered species arguably threatened by the AID-funded projects. ${ }^{85}$ Finally, the Court said, the affidavits left redressability in doubt because (1) even if the DOI retained its consultation requirement, it was unclear that USAID and other federal agencies were bound by it, ${ }^{86}$ and (2) even if such agencies consulted with the DOI and

80. Id. $\$ 1540(\mathrm{~g})$, ELR STAT. ESA $\$ 11(\mathrm{~g})$.

81. Defenders of Wildlife, 504 U.S. at 571-72, 22 ELR at 20918-19.

82. Id. at 578, 22 ELR at 20920.

83. Id. at 573-77, 22 ELR at 20918-20.

84. Id. at 564, 22 ELR at 20916.

85. Id. at 566, 22 ELR at 20917.

86. Id. at 569-71, 22 ELR at 20917-18. 
imposed species-protective conditions on their continued funding of the challenged projects, the foreign nations involved retained the right simply to forego U.S. financial assistance and implement the projects in any event. ${ }^{87}$

There is little doubt that the majority's analysis frustrates the intent of Congress to confer the broadest possible right to sue as a way of ensuring vigorous ESA implementation. It was the majority's position, however, that the Court needs to take special care in assessing standing in cases where the party suing is not itself the subject of the challenged federal action. In such cases, Justice Scalia asserted, standing is "ordinarily 'substantially more difficult' to establish," and it must be so, lest the courts go beyond the legitimate exercise of judicial power and interfere with law enforcement authority conferred by the Constitution on the executive branch. ${ }^{88}$

There is, of course, some irony here. In order to protect what Justice Scalia would hold to be the inherent law enforcement prerogatives of the executive branch, the majority flouts Congress' exercise of legislative power, and makes it easier for the executive branch to do so as well. If the case proceeded to the merits and the plaintiffs lost, then the courts, of course, would be leaving executive discretion intact. On the other hand, if the plaintiffs prevailed, it could only be because the executive branch was overstepping its authorized discretion and falling short of the faithful execution of the ESA. In such a case, judicial intervention would not deprive the executive branch of any constitutional prerogative.

These objections notwithstanding, Defenders of Wildlife portended rough sledding for citizen suits in the Court: "Read for all it is worth, the decision invalidates the large number of statutes in which Congress has attempted to use the 'citizen-suit' device as a mechanism for controlling unlawfully inadequate enforcement of the law." ${ }^{\prime \prime 9}$ Whether the case would be read "for all it is worth" seemed to depend, however, on Justices Kennedy and Souter, whose separate concurrence stated an express willingness to uphold, in other cases, congressional power "to define injuries and articulate chains of causation that will give rise to a case or controversy where none existed before. $" 90$

\section{From Defenders of Wildlife to Laidlaw and Vermont Agency: Putting Injury (Almost) Back in Its Place}

Defenders of Wildlife marked the high watermark for the pleading of injury as a prerequisite to standing. Followed fervently, Defenders of Wildlife promised to limit significantly Congress' capacity to create new public law causes of action. Before a party could seek to compel legal compliance, whether by the government or by another private party, it would have to show that a lack of compliance threatened a nonspeculative injurious impact that the relief sought would redress. It would make no difference to this assessment that Congress had wanted to confer a cause of action expansively. A court could always second-guess the adequacy of the remedial hypothesis underlying the litigant's complaint.

87. Id. at 571,22 ELR at 20918 .

88. Id. at 562, 22 ELR at 20916.

89. Sunstein, supra note 38 , at 165.

90. Defenders of Wildlife, 504 U.S. at 580, 22 ELR at 20920.
Yet, the Court almost immediately withdrew from the most ardent possible reading of Defenders of Wildlife. The very next term, in Northeastern Florida Chapter of Associated General Contractors of America v. City of Jacksonville, Florida, ${ }^{91}$ the city, in a reverse discrimination challenge to its racial set-aside ordinance, argued that the plaintiff nonminority contractors lacked standing because they could not show that overturning the minority set-aside would result in an award to them of the contracts they sought. The Court rejected this plausible Defenders of Wildlife-style challenge on the ground that the denial of an opportunity to compete for the contracts on nonracial criteria was itself a sufficient injury to support standing. A plaintiff did not need to show certainty in reaching its ultimate objective to sustain a finding of redressability. The procedural injury was enough, at least where the plaintiff could show a somewhat particularized interest in the procedural right at stake. ${ }^{92}$ Presumably, this case was factually reconcilable with Defenders of Wildlife on the hypothesis that the plaintiffs in Defenders of Wildlife were less committed to availing themselves of the opportunity to visit specific endangered species habitats abroad than were members of the Northeastern Florida Chapter of Associated General Contractors committed to availing themselves of the opportunity to bid on public works projects in Jacksonville. Unfortunately, the Court has never specified how committed a party needs be to a particular opportunity to make the deprivation of opportunity a redressable injury, irrespective of the party's eventual success in pursuing that opportunity.

In 1997, the Court likewise upheld standing in an ESA case in the face of a yet more speculative remedial hypothesis. The plaintiffs in Bennett v. Spear ${ }^{93}$ were two water districts in Oregon and two ranchers in those districts. The plaintiffs sought to challenge a so-called biological opinion (BO) issued by the FWS, which concluded that continued operation of a particular irrigation project by the Bureau of Reclamation would likely jeopardize the continued existence of two endangered species of fish. As required by law, the BO also identified "reasonable and prudent alternatives" that would avoid jeopardy to the fish habitat, including the maintenance of minimum water levels on two particular reservoirs. The Bureau of Reclamation indicated its intention to follow such alternatives. The plaintiffs argued that the BO was unsubstantiated and that conducting the project under the $\mathrm{BO}$ would reduce the level of available irrigation water and otherwise harm their use of the reservoirs for "recreational, aesthetic and commercial purposes."

The government retorted that the plaintiffs had failed to show injury, causality, or redressability. The plaintiffs had not demonstrated that maintaining higher minimum water levels would result in less water going to the plaintiffs, in particular. Moreover, any reduction in water availability was the result, the government said, not of the $\mathrm{BO}$ of the FWS, but, rather, of the Bureau of Reclamation's independent determination to follow that opinion, which, technically speaking, was not legally compelled. Finally, even if the BO were set aside in Court, the Bureau of Reclamation would retain the legal discretion to retain only minimum water levels in the reservoirs.

91. 508 U.S. 656 (1993).

92. Id. at 666 .

93. 520 U.S. 154, 27 ELR 20824 (1997). 
Copyright $(2000$ Environmental Law Institute $®$, Washington, DC. reprinted with permission from ELRß—The Environmental Law Reporter $®$. All rights reserved.

Justice Scalia, again writing for a majority, nonetheless found that the plaintiffs had standing. Although plaintiffs had not yet shown specific facts to demonstrate that their own water supply would be reduced by the challenged actions, their standing had been dismissed at the pleading stage, where the only question posed should have been whether the complaint stated facts sufficient to make the claim of injury plausible. Plaintiffs met this test. ${ }^{94}$ As for the prospect that the Bureau of Reclamation could or would ignore the challenged $\mathrm{BO}$ and make its own determination of how to proceed, Justice Scalia found that the FWS' BO had a sufficient impact in affecting the Bureau of Reclamation's legal options to have the requisite causal nexus to any decision to elevate reservoir water levels. ${ }^{95}$ Moreover, the $\mathrm{Bu}-$ reau of Reclamation's consistent practice of operating the reservoirs at lower levels before the opinion provided a sufficient guarantee of redressability - namely, that the Bureau of Reclamation would maintain high water levels if the BO were invalidated. ${ }^{96}$

Bennett was a striking decision, in part, because the ESA provisions at stake were the same as those implicated in $D e$ fenders of Wildlife. It also seemed notable that, while the Court had rejected a suit in Defenders of Wildlife that was plainly calculated to further Congress' central objectives in enacting the ESA, the Court was willing to accord standing under the ESA in Bennett to parties seeking to argue that the executive branch was going too far in the protection of endangered species. Of course, the overall significance of Bennett might be limited by the fact that, unlike Defenders of Wildlife, which reviewed plaintiffs' standing at the summary judgment stage, Bennett involved dismissal at the complaint stage, when the plaintiffs' burden of going forward is less onerous. But, however any of these factors may have played into Bennett, a unanimous decision upholding standing in a case where causality and redressability were nonobvious could not help but suggest some limits to the most draconian reading of Defenders of Wildlife.

Justice Scalia had one more opportunity in the late 1990s to suggest limits to the constitutionality of citizen suits. Steel Co. v. Citizens for a Better Environment ${ }^{97}$ involved the Emergency Planning and Community Right-To-Know Act of 1986 (EPCRA). ${ }^{98}$ That Act permits any person to bring a civil action against the owner or operator of a facility that fails in its obligations to file legally required "emergency and hazardous chemical inventory forms" and "toxic chemical release forms" that indicate the facility's storage and use of such chemicals, the waste-disposal methods employed, and the quantities of such chemicals released annually into various environmental media. ${ }^{99}$ Before filing a citizen suit, a would-be plaintiff must give the U.S. Environmental Protection Agency (EPA) 60 days' notice; should EPA itself decide to seek an administrative order or file civil suit, the citizen suit cannot go forward. ${ }^{100}$ In Steel Co., the defendant fa-

94. Id. at 168, 27 ELR at 20827.

95. Id. at 168-70, 22 ELR at 20827.

96. Id. at 170-71, 22 ELR at 20828 .

97. 523 U.S. 83, 28 ELR 20434 (1998). See Jim Hecker, EPCRA Citizen Suits After Steel Co. v. Citizens for a Better Environment, 28 ELR 10306 (June 1998); Jim Hecker, Citizen Standing to Sue for Past EPCRA Violations, 27 ELR 10561 (Nov. 1997).

98. 42 U.S.C. $\S 11001-11050$, ELR STAT. EPCRA $\S 301-330$.

99. Id. $\S \$ 11022,11023$, ELR STAT. EPCRA $\S \S 312,313$.

100. Id. $\$ 11046$, ELR STAT. EPCRA $\$ 326$. cility-upon receiving the 60-day notice of a pending citizen suit-filed all of its overdue forms with the appropriate agencies. When EPA declined to pursue the matter, the plaintiff filed suit, arguing that it still had a cause of action and standing to challenge wholly past violations. The district court disagreed, but the Seventh Circuit Court of Appeals held for the plaintiffs on both points.

Justices Stevens, Souter, and Ginsburg would have dismissed the suit on the ground that EPCRA, properly interpreted, does not authorize citizen suits for wholly past violations. They would have put off the question of constitutional standing because a decision on statutory interpretation would make the standing point moot. A majority preferred, however, to decide the standing question first on the ground that, unless the plaintiffs had standing, the Court had no jurisdiction to decide the EPCRA issue. ${ }^{101}$

Citizens for a Better Environment argued that it had been injured by Steel Company's failure to provide timely information on its storage, use, and disposal of toxics, and that its past violations had continuing effects. They asked for a declaratory judgment that Steel Company violated EPCRA, authority to inspect Steel Company's premises periodically, an order that Steel Company disclose all its compliance reports, an order that Steel Company pay civil penalties for its violations, and an award of attorneys fees and other costs.

The majority found that none of the requested relief would redress the alleged injuries. The declaratory judgment would do nothing because Steel Company did not dispute the fact of its past tardiness. ${ }^{102}$ The orders with respect to future inspections and disclosures could not remedy a past violation, but would only deter future violations - the imminence of which had not been alleged. ${ }^{103}$ A plaintiff's stake in recovering the costs of litigation cannot give the plaintiff enough stake in the litigation to support standing. ${ }^{104}$

This left only the request for civil penalties. The majority held that such payments could not support standing because they would be payable only to the U.S. Treasury. Their payment would not represent "remediation for the costs [plaintiff] incurred as a result of the late filing-but vindication of the rule of law-the 'undifferentiated public interest' in faithful execution of EPCRA." "105 The Court held that such payments were not sufficiently related to a particularized interest of the plaintiffs to support standing. One might easily have concluded from this passage that citizen suits aimed entirely at eliciting the payment of government fines would always run afoul of the Court's current interpretation of Article III standing requirements. ${ }^{106}$

For reasons not altogether clear, the Court has plainly backed away from this reading. Its three most recent decisions on citizen suits have suggested a far greater receptivity to citizen suits than appeared in Defenders of Wildlife or Steel Co.

In Federal Election Commission v. Akins, ${ }^{107}$ the Court acknowledged standing in a group of voters to challenge the

101. Steel Co., 523 U.S. at 89-102, 28 ELR at 20434-39.

102. Id. at 106, 28 ELR at 20438.

103. Justices O'Connor and Kennedy would have found standing if a continuing or imminent violation had been alleged. Id. at 110, 28 ELR at 20444 (O'Connor, J., concurring).

104. Id. at 107-08, 28 ELR at 20438-39.

105. Id. at 106, 22 ELR at 20438.

106. Id. at 107, 22 ELR at 20439.

107. 524 U.S. 11 (1998). 
Federal Election Commission's (FEC's) determination not to treat the American Israel Public Affairs Committee (AIPAC) as a "political action committee" or "PAC" under the Federal Election Campaign Act (FECA), ${ }^{108}$ and not to proceed against AIPAC for violations of that Act. PAC designation imposes on a group extensive organizational, recordkeeping, and disclosure requirements. The FEC's failure to proceed against AIPAC, according to plaintiffs, deprived them of information (donors and campaign-related expenditures and contributions) that AIPAC should have been required to disclose and that would help plaintiffs to evaluate candidates for public office, as well as to evaluate AIPAC's role in specific elections.

The 6-3 vote in favor of standing was notable, in part, because of the seemingly strong resemblance between Akins and the unsuccessful attempt to force the CIA to disclose its budget in Richardson. Although Justice Breyer's opinion for the majority distinguishes the cases on formal grounds and analyzes standing in terms of injury, causality, and redressability, ${ }^{109}$ his reasoning goes some distance to understanding the issues presented in cause of action terms and limiting the standing inquiry to the modest normative concerns that underlie standing doctrine.

As explained by Justice Breyer, the voter plaintiffs have standing to sue because the FECA allows "[a]ny person who believes a violation of this Act ... has occurred [to] file a complaint with the [FEC]," 110 and provides that "[a]ny party aggrieved by an order of the [FEC] dismissing a complaint filed by such party" may seek judicial review. ${ }^{111}$ The word "aggrieved," he determined, is to be read broadly, especially where the interests asserted by the complaining party are plainly among those intended to be protected by the statute at issue. The majority thus deemed wholly irrelevant the taxpayer standing analysis held applicable under the constitutional provision invoked in Richardson. ${ }^{112}$ This could easily be understood as saying that the FECA implies a cause of action for voters to sue to obtain information that is not implied for voters under an information disclosure provision of the Constitution.

As for the obvious argument that the Akins plaintiffs asserted only a "generalized grievance" characteristic of all voters, the majority expressly declines to treat the matter as an additional formal test of standing. ${ }^{113}$ Instead, the Court expressly roots prior discussions of the generalized grievance problem in the normative concern that actually underpins Article III standing requirements - the need to avoid abstract review. The Court states:

The kind of judicial language [about "generalized grievances"] to which the FEC points, however, invariably appears in cases where the harm at issue is not only widely shared, but is also of an abstract and indefinite nature-for example, harm to the "common concern for obedience to law." The abstract nature of the harm ... deprives the cases of the concrete specificity that characterized those controversies which were "the traditional concern of the courts at Westminster," and which today prevents a plaintiff from obtaining what would, in effect,

108. 86 Stat. 11, as amended, 2 U.S.C. \$431(4).

109. Akins, 524 U.S. at 20-25.

110. 2 U.S.C. $\$ 437 \mathrm{~g}(\mathrm{a})(1)$.

111. Id. $\$ 437 \mathrm{~g}(\mathrm{a})(8)(\mathrm{A})$.

112. Akins, 524 U.S. at 21-23.

113. Id. at 23-35. amount to an advisory opinion. Often, the fact that an interest is abstract and the fact this it is widely shared go hand in hand. But their association is not invariable, and where a harm is concrete, though widely shared, the Court has found "injury-in-fact." 114

This analysis makes perfect sense, except that it neglects to explain precisely in what way the injury to plaintiffs in Akins is more concrete than-or, indeed, not practically identical to - the injury asserted in Richardson. The most sensible inference is that what "concretized" the injury in Akins was the congressional determination to make a voter's interest in PAC disclosure a legally protectible interest. The plaintiff in Richardson ought now be understood as having lacked "standing" only in the sense that the Constitution does not imply a legal right to sue to enforce the Statement and Account Clause, and not because there was any other constitutional infirmity in his pleading.

The implications of Steel Co. were similarly narrowed in Laidlaw. ${ }^{115}$ Friends of the Earth sued Laidlaw under the citizen suit provisions of the CWA, which permit civil actions on behalf of "a person or persons having an interest which is or may be adversely affected." 116 Violators may be subjected to injunctive relief, but also to the compulsory payment of civil fines to the U.S. Treasury. ${ }^{117}$ As in Steel Co., the defendant had achieved substantial legal compliance by the time of trial, so that injunctive relief was denied. The trial court nonetheless imposed a civil fine of $\$ 405,800$ and awarded significant costs to Friends of the Earth. One might have expected that, with injunctive relief out of the picture, standing to seek civil fines for past misconduct - the very action thrown out in Steel Co. - would also cease to exist. Over a vigorous Scalia dissent, joined by Justice Thomas, seven Justices disagreed.

As analyzed by the majority, Laidlaw's substantial compliance with the terms of its discharge permit, occurring after the filing of suit, may have mooted the request for injunctive relief, but did not destroy standing. Various Friends of the Earth members alleged that they used the area affected by Laidlaw's discharge, and that Laidlaw's activities not only reduced the aesthetic and recreational appeal of the area, but aroused their concern about environmental harms and impact on their property values. These allegations were deemed more specific than those of the Defenders of Wildlife members who filed affidavits in Defenders of Wildlife. ${ }^{118}$

But, most remarkably, the Court expressly rejected the proposition that civil fines to the U.S. Treasury do not redress injuries to private plaintiffs. The majority expressly deferred to congressional determinations that CWA fines are appropriate not only to compensate for past harms, but to punish the wrongdoer and deter future misconduct. ${ }^{119}$ Writing for the Court, Justice Ginsburg explained:

114. Id. at 23-24.

115. 120 S. Ct. at 693, 30 ELR at 20246. For discussions of Laidlaw, see Craig N. Johnston, Standing and Mootness After Laidlaw, 30 ELR 10317 (May 2000); Michael P. Healy, Standing in Environmental Citizens Suits: Laidlaw's Clarification of the Injury-in-Fact and Redressability Requirements, 30 ELR 10455 (June 2000); Daniel A. Farber, Environmental Litigation After Laidlaw, 30 ELR 10516 (July 2000).

116. 33 U.S.C. $\S \$ 1365(a),(g)$, ELR STAT. FWPCA $\S 505(a)$, (g).

117. Id. §1365(a), ELR STAT. FWPCA §505(a).

118. Laidlaw, 120 S. Ct. at 705-06, 30 ELR at 20249.

119. Id. at 706, 30 ELR at 20249. 
Copyright $(2000$ Environmental Law Institute $®$, Washington, DC. reprinted with permission from ELR®—The Environmental Law Reporter $®$. All rights reserved.

It can scarcely be doubted that, for a plaintiff who is injured or faces the threat of future injury due to illegal conduct ongoing at the time of suit, a sanction that effectively abates that conduct and prevents its recurrence provides a form of redress. Civil penalties can fit that description. To the extent that they encourage defendants to discontinue current violations and deter them from committing future ones, they afford redress to citizen plaintiffs who are injured or threatened with injury as a consequence of ongoing unlawful conduct. ${ }^{120}$

Justice Ginsburg's straightforward analysis casts obvious doubt about the vitality of both Steel Co. and Linda R.S. She distinguishes the former on the ground that, unlike Laidlaw, Steel Co. did not involve "violations that [were] ongoing at the time of the complaint and that could continue in the future if undeterred." ${ }^{21}$ As for Linda R.S., the majority holds, in essence, that criminal prosecution is simply different and that the incarceration of the father of Linda R.S.'s child - an obvious potential outcome of the criminal prosecution she sought to have initiated - would have weakened his capacity to fulfill his financial obligations to Linda R.S. ${ }^{122}$ These are factual distinctions, to be sure. That they are sufficiently weighty, however, to render adjudication unconstitutional in the earlier cases, but not in Laidlaw is questionable - especially if the relevant inquiry is whether either case entails the kind of abstract review that is outside the realm of disputes historically deemed suitable for judicial resolution.

In addition to citizen suits, there is, of course, yet another form of lawsuit in which the plaintiff seeks to recover a fine and damages for the benefit of the United States-qui tam litigation. As explained in Vermont Agency, ${ }^{123}$ "[q] ui tam is short for the Latin phrase qui tam pro domino rege quam pro se ipso in hac parte sequitur, which means 'who pursues this action on our Lord the King's behalf as well as his own." "124 Although early Congresses enacted numerous qui tam statutes, only four apparently remain on the books, the most important of which is the FCA. ${ }^{125}$ Under the FCA, a person who presents or causes to be made a false or fraudulent claim for payment to the United States is subject to up to treble damages, as well as a civil fine of up to $\$ 10,000 .{ }^{126}$ The FCA qui tam provision authorizes "a private person (the 'relator') [to] bring a qui tam civil action 'for the person and for the United States Government' against the alleged false claimant, and 'in the name of the Government." ${ }^{12}$ It would be hard to improve on the Court's succinct summary of qui tam procedure:

If a relator initiates the FCA action, he must deliver a copy of the complaint, and any supporting evidence, to the Government, which then has 60 days to intervene in the action. If it does so, it assumes primary responsibility for prosecuting the action, though the relator may continue to participate in the litigation and is entitled to a hearing before voluntary dismissal and to a court determination of reasonableness before settlement. If the

120. Id.

121. $I d$. at 708,30 ELR at 20250 .

122. $I d$. at 708 n.4, 30 ELR at 20250 n.4.

123. $120 \mathrm{~S}$. Ct. at 1858, $30 \mathrm{ELR}$ at 20622.

124. Id. at 1860 n.1, 30 ELR at 20622 n.1.

125. Id. at $1860 \&$ n.1, 30 ELR at $20622 \&$ n. 1.

126. 31 U.S.C. $\$ 3729$ (a).

127. Vermont Agency, 120 S. Ct. at 1860, 30 ELR at 20623 (citing 31 U.S.C. $\$ 3730(b)(1))$.
Government declines to intervene within the 60-day period, the relator has the exclusive right to conduct the action, and the Government may subsequently intervene only on a showing of "good cause." The relator receives a share of any proceeds from the action - generally ranging from 15 to 25 percent if the Government intervenes (depending upon the relator's contribution to the prosecution), and from 25 to 30 percent if it does not (depending upon the court's assessment of what is reasonable) - plus attorney's fees and costs. ${ }^{128}$

Under these provisions, an FCA qui tam suit thus differs from the CWA-type citizen suit in two key ways: There is no statutory requirement that, in any sense, the qui tam plaintiff be a party whose interests have been or will be adversely affected by the defendant's conduct. On the other hand, if the qui tam plaintiff wins, the prize is a significant portion of the monetary award. Thus, the qui tam plaintiff has a direct monetary stake in the outcome of the litigation which the plaintiff in Laidlaw lacked.

The only legal issues presented originally on certiorari in Vermont Agency were whether a state agency was a "person" subject to FCA liability, and, if so, whether a suit against a state agency under the FCA was consistent with the Eleventh Amendment. ${ }^{129}$ Shortly before oral argument, however, the Court sua sponte invited argument on the question whether qui tam suits were compatible with Article III standing requirements - a point on which Justice Scalia had expressed some skepticism at oral argument. ${ }^{130}$ Nonetheless, the Court unanimously-with Justice Scalia writing - upheld the constitutionality of qui tam suits, while dividing 7-2 in concluding that states are not subject to qui tam suits under the FCA.

Returning to ADAPSO, Vermont Agency should surely have appeared an easy case. No question was raised whether Vermont Agency was presented "in an adversary context." Nor could it be doubted that qui tam suits represent litigation "in a form historically viewed as capable of judicial resolution." Not only did early Congresses enact statutes authorizing qui tam suits expressly, but the Court early on treated statutes that provide rewards to informers as implicitly authorizing private suits for their recovery. ${ }^{131}$ As noted above, the first four Congresses enacted 23 statutes that permitted qui tam suits, whether expressly or by implication. ${ }^{132}$

The Court might well have left matters there, ignoring, as it were, what should be the wholly extraneous issue of injury-in-fact. Instead, Justice Scalia invoked the injury requirement, but concluded that, for Article III purposes, it did not matter whether the injury at issue was one to the plaintiff. It was enough that the United States had been injured, and that the United States, by implication, had "assigned" part of its right of recovery to the qui tam relator, or plaintiff. ${ }^{133}$ The Court, he noted, has routinely allowed suits by both assignees and by subrogees, "who have been de-

128. Id. at 1861, 30 ELR at 20623 (citations omitted).

129. Id. at 1861, $30 \mathrm{ELR}$ at 20623.

130. See France, supra note 5, at 32.

131. United States ex rel. Marcus v. Hess, 317 U.S. 537, 541 n.4 (1943) (citing Adams v. Woods, 6 U.S. (2 Cranch) 336, 341 (1805)).

132. Supplementary Brief for Respondent at 7 n.3, Vermont Agency of Natural Resources v. United States ex rel. Stevens, 120 S. Ct. 1858, 30 ELR 20622 (2000) (No. 98-1828) (1999 WL 1276923).

133. Vermont Agency, 120 S. Ct. at 1863, 30 ELR at 20623. 
Copyright $@ 2000$ Environmental Law Institute $®$, Washington, DC. reprinted with permission from ELRß—The Environmental Law Reporter@. All rights reserved.

scribed as "equitable assign[ees]." "134 He might have added that other formal representatives, such as trustees and guardians, also sue routinely in federal court. ${ }^{135}$ Based on such precedents, the Court concluded "that the United States' injury-in-fact suffices to confer standing" on a qui tam plaintiff. ${ }^{136}$

This common-sense observation only makes more transparent that an injury inquiry is not quite what an Article III standing analysis ought to involve. The issue standing presents is whether the suit involves abstract review, given the nature of the claim asserted and plaintiff's relationship to that suit. That a lawsuit focuses on a concrete injury, especially an injury to the plaintiff, may be a good guide as to its concreteness and genuinely adversarial nature. But Congress should still be able to authorize lawsuits that entail concrete, factually developed, genuinely adversarial litigation, whether or not based on an injury. After all, if the injury on which a suit is based need not have targeted the plaintiff - indeed, if the injury involved can be an injury to the United States - then there seems to be no constitutional reason why Congress cannot identify as it chooses the kinds of interests, whether private or public, that federal litigants should be deemed to have standing to protect. The Article III limitations on Congress' power should go only to the imperatives to avoid collusive adjudication or abstract review-advisory opinions, adjudication that does not result in binding judgment, or disputes based on facts too vague and ill-defined for definitive assessment.

Federal litigators now face the obvious question of what Akins, Laidlaw, and Vermont Agency leave standing, so to speak, of Defenders of Wildlife. None of the three later cases expressly calls into question the injury-causalityredressability approach to standing. Yet, Akins stands in clear tension with Justice Scalia's Defenders of Wildlife contention that standing is "substantially more difficult" to establish" in cases in which the plaintiff "is not himself the object of the government action or inaction" that is being challenged. Laidlaw stands for the proposition that citizen plaintiffs can claim redressability even when the sought-after relief runs in favor of the government, not the plaintiffs per se. Vermont Agency underscores that the United States can assign its interests in particular remedies, whether in whole or in part, to private representative plaintiffs. What is left of Defenders of Wildlife seems chiefly to be the concurring opinion of Justices Kennedy and Souter, who would have denied standing chiefly on the basis that, given their reading of the record, "respondents . . . failed to demonstrate that they themselves [were] 'among the injured.",137

Such a judgment call seems harder to sustain after Akins. The concurring Justices themselves wrote: "[I]t may seem trivial to require that [members of the plaintiff environmental group] acquire airline tickets to the project sites or announce a date certain upon which they will return. . . ."138 It seems far more trivial now that plaintiff voters have been deemed sufficiently injured by the nondisclosure of a

134. $I d$.

135. Supplementary Brief for Respondent at 5, Vermont (No. 98-1828) (1999 WL 1276923) (citing Charles A. Wright et Al., 13 Federal Practice and Procedure $\$ 3531.9$, at 627 (1984)).

136. Vermont Agency, $120 \mathrm{~S}$. Ct. at 1863, 30 ELR at 20624.

137. Defenders of Wildlife, 504 U.S. at 579, 22 ELR at 20920 (Kennedy, J., concurring).

138. $I d$. third-party political organization's history of contributions and expenditures to challenge the FEC's decision not to treat the organization as a PAC. To the extent there is even a metaphysical difference in the concreteness or particularity of the injuries in Defenders of Wildlife and Akins, Defenders of Wildlife would seem to be the stronger, not the weaker suit, in standing terms.

The stakes, however, are more than doctrinal. Justice Scalia has been explicit and consistent in outlining a normative case for the kind of strict approach to injury he adumbrated in Lujan:

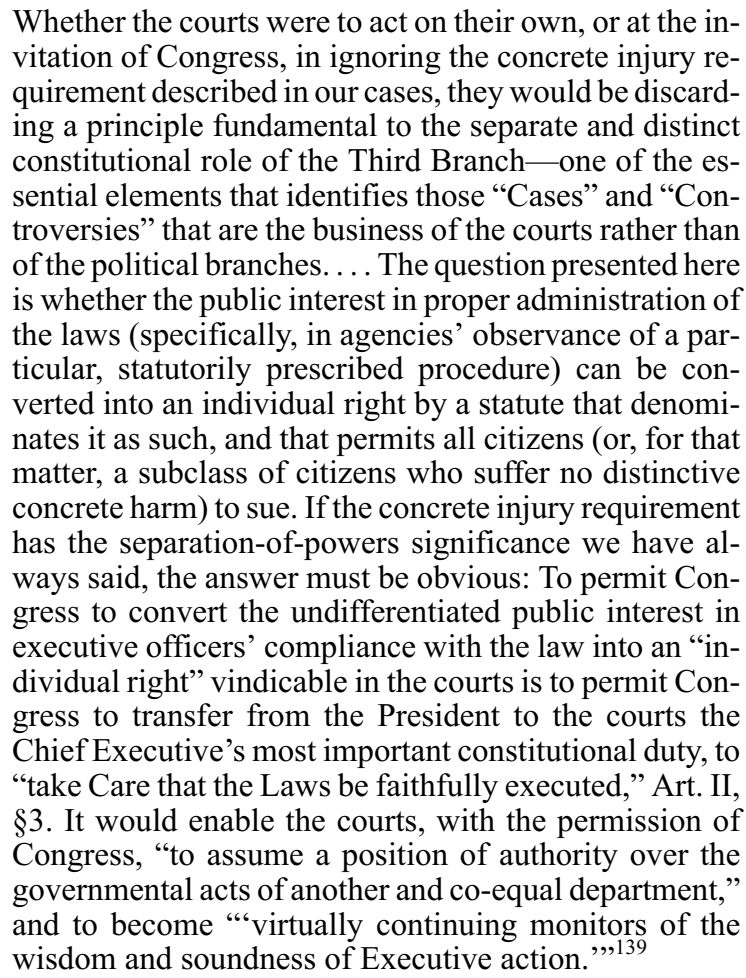

In other words, Justice Scalia's understanding of the primary function of standing doctrine is the insulation of the elected branches from judicial overreaching.

At a sufficient level of abstraction, this understanding is unobjectionable. In large part, however, Akins, Laidlaw, and Vermont Agency help explain why this normative view has little to do with the injury requirement. Plaintiffs in citizen or qui tam suits follow one of two possible fates - they lose or they win. If they lose, whether the defendant is the government or a private party, the government's discretion remains intact. If they win against a private party, the result can only be deemed consistent with the constitutional command that the laws "be faithfully executed." A plaintiff's victory hardly undermines the executive obligation to "take care" that faithful execution occur. (And, of course, in the actions at issue in Laidlaw and Vermont Agency, Congress even authorized the executive to take control of the litigation at its discretion.) If a private plaintiff wins against the government, then it must be because the executive branch was failing in its constitutional obligation. In such a case, judicial correction of an executive error of law, or even judicial action that constrains the executive branch to deploy its discretion in a nonarbitrary, noncapricious way, is again fully consistent with the executive branch's constitutional

139. Id. at 576-77, 22 ELR at 20919. 
Copyright $@ 2000$ Environmental Law Institute $®$, Washington, DC. reprinted with permission from ELR®—The Environmental Law Reporter $®$. All rights reserved.

obligations. Whether the lawsuit involves an injury peculiar to the plaintiff is beside the point.

A more compelling normative basis for standing doctrine lies in the self-protection of the judiciary. Rendering judgment in collusive suits, requests for advisory opinions, suits that are factually underdeveloped, or suits in which a court's pronouncement could be administratively altered would "cheapen the currency" of judgment, so to speak. A collusive suit presents no compelling need for law pronouncement. Advisory suits and suits based on sketchy, abstract records run too great a risk of eliciting judgments that the Court, on fuller understanding, will come to regret. A judgment that the Executive could revise administratively would not be a resolution of any party's legal rights, but a subsidiary act of administration. Because the judiciary has "neither Force, nor Will, but only Judgment" $" 140$ to fulfill its duties, the definitive and public character of "Judgment" must be preserved. For federal courts to resolve on their merits those lawsuits brought by environmental groups against the federal government is entirely consistent with this principle. If a lawsuit is presented in a genuinely adversarial context and in a form historically viewed as capable of judicial resolution, then Congress ought to be able to create causes of action against the federal government that can complement the Executive's own efforts "to take Care that the Laws be faithfully executed."

As a threshold matter, a federal court should concern itself in most cases only with whether Congress has conferred on the plaintiff a legal right of action to file suit. If the answer is affirmative, there should be no other standing issue to resolve.

\section{Executive Power and Private Suits to Enforce Civil Fines}

Riley: Article II Challenges to Qui Tam Litigation

One might well think that the history that persuaded the Vermont Agency Court that Article III permits qui tam actions would resolve all separation-of-powers objections to qui tam litigation. After all, the textual allocation of powers among the three branches of the national government has remained intact since 1787, and the practices of early Congresses are typically regarded as authoritative on the contemporaneous understanding of the entire original Constitution, not just Article III. ${ }^{141}$ Yet, a footnote in the Scalia opinion expressly reserves the question whether qui tam litigation is consistent with the constitutional allocation of executive power: "[W]e express no view on the question whether qui tam suits violate Article II, in particular the Appointments Clause of $\S 2$ and the 'take Care' Clause of $\$ 3$."142

The premise of both an Appointments Clause ${ }^{143}$ challenge and a Faithful Execution Clause ${ }^{144}$ challenge to qui tam suits is the same: It is that litigation to collect fines for the federal treasury is an instance of "executive power" that the President must control pursuant to his obligation to "take

140. The Federalist No. 78, at 465 (James Madison) (Clinton Rossiter ed., 1961).

141. Vermont Agency, 120 S. Ct. at 1878, 30 ELR at 20627 (Stevens, J., dissenting).

142. Id. at 1865 n.8, 30 ELR at 20624 n.8.

143. U.S. Const. art. II, §2, cl. 2.

144. Id. art. II, $\S 3$.
Care that the Laws be faithfully executed," and which may thus be implemented only by an "Officer of the United States." A Fifth Circuit Court of Appeals panel accepted these premises in holding the FCA qui tam authority unconstitutional in late 1999. Riley ${ }^{145}$ is a qui tam suit filed against St. Luke's, a Houston hospital, and seven other defendants by a former nurse in St. Luke's heart transplant unit; she alleged that the defendants had defrauded the United States in unnecessarily admitting patients and upgrading their services, and in charging two federal medical insurance programs for the services of an unlicensed physician. The trial court, pre-Vermont Agency, held that the qui tam suit violated Article III's standing requirements. ${ }^{46}$ The appellate panel reversed, on the ground that a prior Fifth Circuit panel had already reached this issue in another case - albeit after the Riley district court entered its judgment - thus foreclosing the Riley panel from entertaining the standing challenge anew. ${ }^{147}$ This was plainly frustrating to the Riley majority, which described the lower court standing opinion as "scholarly and persuasive." 148

The Riley panel then proceeded, however, to analyze the constitutionality of the FCA qui tam authority under arguments the district court had not reached, namely, those asserting violations of Article II. Every other court to hear these arguments had rejected them. ${ }^{149}$ Nonetheless, the panel discerned a breach of separation-of-powers principles because qui tam authority "strip[s] the Executive branch of its exclusive prosecution power," ${ }^{150}$ and places that power in the hands of a person not subject to Article II appointment. The victory for qui tam opponents may prove short-lived, however. On the same day that the Riley panel published its opinion, the Fifth Circuit published its sua sponte order directing the case to be reheard en banc. ${ }^{151}$

\section{Morrison or Printz? Contending Supreme Court Approaches to the Analysis of Executive Authority}

On the Court, the strongest champion of a view of executive power that is plausibly as categorical as the view taken in Riley has been Justice Scalia (with Justice Kennedy seemingly in accord). He articulated his view most recently in a case that demonstrates clearly just how emphatic a position

145. 196 F.3d at 514, reh'g en banc granted, 196 F.3d at 561.

146. United States ex rel. Riley v. St. Luke's Episcopal Hosp., 982 F. Supp. 1261, 1263-69 (S.D. Tex. 1997).

147. Riley, 196 F.3d at 521 (citing United States ex rel. Foulds v. Texas Tech. Univ., 171 F.3d 279, 288 n.12 (5th Cir. 1999)).

148. Id. at 517. Technically, the majority that found the earlier panel decision preclusive of a denial of standing was not the same majority that found the opinion below "scholarly and persuasive." Judge Jerry Smith, writing for himself and concurring Judge DeMoss, constituted the majority that found the lower court opinion so convincing. Judge DeMoss, however, did not think the earlier panel decision sufficiently considered the Article III issue to conclude the problem of standing. Id. at 535-39 (DeMoss, J., concurring). Judge Stewart, who dissented from Judge Smith's Article II opinion, agreed with Judge Smith, however, that the Article III standing issue had already been resolved by Fifth Circuit precedent. Id. at 543 n.2 (Stewart, J., dissenting).

149. United States ex rel. Taxpayers Against Fraud v. General Elec. Co., 41 F.3d 1032, 1041 (6th Cir. 1994); United States ex rel. Kelly v. Boeing Co., 9 F.3d 743, 757 (9th Cir. 1993); United States ex rel. Kreindler \& Kreindler v. United Technologies Corp., 985 F.2d 1148, 1155 (2d Cir. 1993).

150. Riley, 196 F.3d at 524 .

151. Id. at 561 . 
Copyright $@ 2000$ Environmental Law Institute $\circledast$, Washington, DC. reprinted with permission from ELRß—The Environmental Law Reporter $®$. All rights reserved.

he holds. Printz v. United States ${ }^{152}$ invalidated a portion of the 1993 Brady Handgun Violence Prevention Act. ${ }^{153}$ Congress had accurately anticipated the creation within five years of a computerized National Instant Check System (NICS) to facilitate immediate determinations as to the eligibility of would-be gun owners to buy weapons. But, in order to promote such checks before NICS went on-line, Congress required local police to cooperate in determining whether proposed firearms sales would be lawful. By a 5-4 vote, the Court held that "commandeering" local law enforcement officials to help administer a federal regulatory program, even on a temporary basis, violated the principles of federalism codified in the Tenth Amendment to the Constitution. ${ }^{154}$

Justice Scalia, writing for the majority, also offered what Professor Tribe has called a "somewhat startling alternative holding" $" 155$ for the partial invalidation of the Brady Act. Namely, Scalia wrote that the Act violated Article II by delegating federal identity-checking authority to local police officials, who are not in a chain of command that subjects them to control by the President of the United States:

The Constitution does not leave to speculation who is to administer the laws enacted by Congress; the President, it says, "shall take Care that the Laws be faithfully executed," Art. II, §3, personally and through officers whom he appoints (save for such inferior officers as Congress may authorize to be appointed by the "Courts of Law" or by "the Heads of Departments" who are themselves Presidential appointees), Art. II, §2. The Brady Act effectively transfers this responsibility to thousands of CLEOs [i.e., chief law enforcement officers] in the 50 States, who are left to implement the program without meaningful Presidential control (if indeed meaningful Presidential control is possible without the power to appoint and remove). The insistence of the Framers upon unity in the Federal Executive - to ensure both vigor and accountability - is well known. That unity would be shattered, and the power of the President would be subject to reduction, if Congress could act as effectively without the President as with him, by simply requiring state officers to execute its laws. ${ }^{156}$

In other words, executive power includes all power to administer federal law, and all such administrative power must be wielded by a presidential subordinate.

It is not hard to see why the Riley panel would find this analysis inconsistent with qui tam actions. Starting from the premise that the executive charge to take care that the laws be faithfully executed encompasses the litigation of claims on behalf of the United States, the panel discerned that the claims at the heart of qui tam actions must be pursued by persons subject to presidential control. ${ }^{157}$ Because the president does not control qui tam relators, it would follow that such private plaintiffs may not engage in litigation on behalf of the United States.

And, yet, it is intriguing to note that the Riley panel did not precisely rely on Printz. Instead, the court cited as control-

\footnotetext{
152. 521 U.S. 898 (1997).

153. Pub. L. No. 103-159, 107 Stat. 1536.

154. Printz, 521 U.S. at 933.

155. TRIBE, supra note 14 , at 715.

156. Printz, 521 U.S. at $922-23$.

157. Riley, 196 F.3d at 525-29.
}

ling authority the Supreme Court's 1988 decision in Morrison v. Olson, ${ }^{158}$ which upheld the independent counsel provisions of the Ethics in Government Act. There is an obvious tension on this point. Although the categorical alternative holding of Printz is not easily reconciled with the more subtle balancing test of Morrison, it would be highly surprising if the Printz Court intended to overrule Morrison. The Printz majority included both Chief Justice Rehnquist, who authored Morrison, and Justice O'Connor, who had joined the earlier Rehnquist opinion.

The central issue in Morrison was the permissibility under Article II of delegating criminal prosecution functions to a judicially appointed prosecutor who could be removed only by the Attorney General, and only under a highly constrained "good cause" requirement. Theodore B. Olson, a former assistant attorney general who had been targeted for an independent counsel investigation on allegations of testifying falsely to Congress, argued that criminal prosecution was an inherently executive function. As such, it was within the executive power vested generally in the President and encompassed also by his faithful execution obligation. And, thus, Olson contended, the function of prosecuting criminals could be implemented only by an officer subject to direct policy control by the President.

In a 7-1 vote, with Justice Kennedy having recused himself, the Court rejected the entirety of the Olson argument. It explicitly dismissed the notion that the constitutionality of delegating governmental functions to persons beyond direct presidential control could be settled by the proper characterization of those functions as "executive" or something else:
[O]ur present considered view is that the determination of whether the Constitution allows Congress to impose a "good cause"-type restriction on the President's power to remove an official cannot be made to turn on whether or not that official is classified as "purely executive."... We do not mean to suggest that an analysis of the func- tions served by the officials at issue is irrelevant. But the real question is whether the removal restrictions are of such a nature that they impeded the President's ability to perform his constitutional duty, and the functions of the officials must be analyzed in that light. ${ }^{159}$

The Court concluded specifically that, because the Attorney General (who is subject to presidential control) can remove an independent counsel for misconduct, the President's duty to take care that the laws be faithfully executed remains intact. ${ }^{160}$ The arrangement leaves a vast range of prosecutorial discretion in the hands of an official who is not subject to policy supervision by the Attorney General or anyone else. But, the Court said summarily, "we simply do not see how the President's need to control the exercise of that discretion is so central to the functioning of the Executive branch as to require as a matter of constitutional law that the counsel be terminable at will by the President.,"161

This line of analysis is plainly at odds with the alternative holding of Printz, which is a view of executive power seemingly identical to that expressed in Justice Scalia's bitter

158. 487 U.S. 654 (1988).

159. Id. at $689-90$ (emphasis added).

160. Id. at 692 .

161. Id. at 691-92. 
Copyright $(2000$ Environmental Law Institute $®$, Washington, DC. reprinted with permission from ELR®—The Environmental Law Reporter $®$. All rights reserved.

Morrison dissent. ${ }^{162}$ Nonetheless, the Riley panel makes a heroic attempt to apply the Morrison test in a way that will produce a Printz-type analysis. The attempt is unpersuasive for four reasons that I will explore in detail below. First, taking the cases on their face, it cannot seriously be argued that the President's capacity to discharge his constitutional obligations is compromised more seriously by qui tam litigation than by the judicial appointment of independent counsel who are not subject even indirectly to the President's policy control. Second, the Riley analysis, if taken seriously, would cut a vast swath through elements of our national structure of public administration that have evolved without serious legal challenge for more than a century. Third, the Scalia-Riley view of the unitary Presidency cannot be defended on the very normative terms on which it purports to be based, namely, those of accountability and political responsiveness. Finally, the Scalia-Riley view, as a historical matter, is simply wrong.

\section{Why Qui Tam Suits Are Permissible Under Article II}

\section{Parsing the Cases}

The Riley panel argues that qui tam litigation really does "impede [...] the President's ability to perform his constitutional duty, $" 163$ to a degree that the Ethics in Government Act does not. The constitutional duty, or duties, identified in Riley involve "(1) the discretion to decide whether to prosecute a claim and (2) the control of litigation brought to protect the government's interest." ${ }^{164}$ The FCA purportedly interferes with these duties in the following ways: (1) relators may initiate suit when the U.S. Department of Justice (DOJ) declines to do so; (2) if DOJ does pursue the suit, it may settle or dismiss the matter over the relator's objections only if the court approves after a hearing; and (3) the DOJ can limit the relator's participation in the suit only with a court's ap-

162.

[I]t is ultimately irrelevant how much the [Ethics in Government Act] reduces Presidential control. The case is over when the Court acknowledges, as it must, that "[i]t is undeniable that the Act reduces the amount of control or supervision that the Attorney General and, through him, the President exercises over the investigation and prosecution of a certain class of alleged criminal activity." It effects a revolution in our constitutional jurisprudence for the Court, once it has determined that (1) purely executive functions are at issue here, and (2) those functions have been given to a person whose actions are not fully within the supervision and control of the President, nonetheless to proceed further to sit in judgment of whether "the President's need to control the exercise of [the independent counsel's] discretion is so central to the functioning of the Executive Branch" as to require complete control, whether the conferral of his powers upon someone else "sufficiently deprives the President of control over the independent counsel to interfere impermissibly with [his] constitutional obligation to ensure the faithful execution of the laws," and whether "the Act give[s] the Executive Branch sufficient control over the independent counsel to ensure that the President is able to perform his constitutionally assigned duties." It is not for us to determine, and we have never presumed to determine, how much of the purely executive powers of government must be within the full control of the President. The Constitution prescribes that they all are.

Id. at 708-09 (Scalia, J., dissenting).

163. Id. at 690 .

164. Riley, 196 F.3d at 526. proval and cannot remove the relator as a party once it allows the suit to move forward. ${ }^{165}$

In contrast, according to the Riley majority, the Ethics in Government Act intrudes less into executive discretion. ${ }^{166}$ First, the Attorney General has unreviewable discretion not to seek the appointment of an independent counsel in the first place, which preserves part of the Executive's supposed power to decide whether to prosecute a claim. In addition, the Attorney General may remove independent counsel for good cause. The jurisdiction of an independent counsel is defined with reference to the facts submitted by the Attorney General to the panel appointing the independent counsel. And the Ethics in Government Act requires independent counsel to abide by preexisting DOJ prosecutorial policies wherever possible. These features of the Ethics in Government Act help preserve the supposed executive power to control whatever litigation is brought to protect the government's interests.

But this recitation of the comparative impact of each statute on DOJ decisionmaking is triply misguided. First, the major premise - that "(1) the discretion to decide whether to prosecute a claim and (2) the control of litigation brought to protect the government's interest" are constitutionally reserved to the executive - is not the premise that the Morrison Court adopts. The constitutional duty to which Morrison refers is the duty "to take care that the laws be faithfully executed." ${ }^{\prime 67}$ With regard to counsel litigating on behalf of the United States, that duty does not entail policy control over all government litigation, but consists instead of assuring "that ... counsel [representing the United States] is competently performing her statutory responsibilities in a manner that comports with the [underlying] provisions of [law]." "168 The accommodations to executive discretion that Morrison cites - the power to keep any prosecutor from appearing where none is legally justified, the power to discharge for misconduct, the power to guide the grant of jurisdiction, and the power to confine to preexisting DOJ policy - are not constitutionally significant because they accommodate the Executive's control of litigation per se. Rather, they are important because they enable the Executive to ensure, to an important degree, that independent counsel are appointed only when consistent with law and that, once appointed, independent counsel comply with the law.

To understand why these particular controls are essential to the executive in assuring faithful execution of the Ethics in Government Act, it is critical to note that independent counsels are criminal prosecutors, not civil litigants. Since the abolition of private prosecutions in the United States, no private citizen in the United States can subject another private citizen to the unique and virtually unfettered powers of a criminal prosecutor. Private citizens do not become litigants in criminal actions except as defendants. The burdens of criminal investigation cannot be imposed on any target unless the investigator has been duly clothed with the power of the state through a process that is legally and politically

165. Id. at 526-27.

166. Id. at 527-28.

167. "This is not a case in which the power to remove an executive official has been completely stripped from the President, thus providing no means for the President to ensure the 'faithful execution' of the laws." Morrison, 487 U.S. at 692.

168. Id 
accountable. Had Congress not enabled the Attorney General to veto the appointment of independent counsel, this rule could have been largely subverted. Private individuals might well have found themselves facing unique and virtually unfettered prosecutorial powers, but wielded by an individual who did not enjoy any mandate from a politically accountable authority.

In the American tradition, the presence of political accountability over prosecutorial officials has more to do with basic notions of due process than with the protection of a unitary executive. Some such accountability is important because a criminal prosecutor may deploy his or her authorities against investigative targets for an extended period of time with virtually no judicial supervision. Such legal supervision as may exist - in the convening of grand juries or the grant of search warrants, for example-is extremely deferential to the prosecutor, and offers little protection against the possibility of prosecutorial overreaching or unfairness. It is in this extraordinary context that placing ordinary prosecutors within politically accountable offices or departments offers at least a modest promise of institutional restraint in the use of prosecutorial authority. Ordinary prosecutors are subject to the discipline imposed by the necessity to pursue an effective prosecutorial agenda within limited resources. In making case-by-case judgments, they are guided by broader and sometimes published policies that are formulated to guide their discretion generally. Their sensible exercise of self-discipline and their observance of general policy are promoted by the political accountability of whoever sits atop their prosecutorial agency.

Equivalent political accountability would, of course, largely undermine the reason for having independent counsels. Because of the potential conflicts of interest, no political official is given complete policy control over an independent counsel. The statutory controls on independent counsels on which Morrison relies and to which Riley refers are intended, however, to subject independent counsels to a degree of institutional discipline that is roughly equivalent to the controls faced by ordinary prosecutors. Hence, while they are free from ordinary political supervision, independent counsels, unlike ordinary prosecutors, may not delimit their own jurisdiction. In fulfilling their role, they are statutorily bound to follow preexisting DOJ policies. They are subject to administrative removal for misconduct. If not for these controls, independent counsels would enjoy a virtually unique degree of unfettered discretion unsupervised by anyone to bring the extraordinary coercive investigative capacity of the government to bear against private individuals that is simply unheard of in the criminal justice system. To be sure, the fetters imposed by the Ethics in Government Act may be too weak to accomplish their goal. The point is that they exist not to protect the unitariness of the executive, but to protect against the arbitrary treatment of potential prosecutorial targets.

Qui tam relators are not in an analogous position to criminal prosecutors. They are civil litigants. The leverage they can exercise over private defendants is leverage indistinguishable from that which is available to any would-be private civil litigant. In order to invoke the coercive power of the state, a civil litigant must file suit, which immediately subjects him or her to the supervisory authority of a court. There is never a period of time when a civil plaintiff enjoys unique authority over a target defendant that is not subject to ready judicial control. In a civil dispute, the executive branch does not need to be able to prevent the filing of suit, or to fire a qui tam litigator, or to confine the relator's jurisdiction, or to bind the relator to DOJ litigating policy in order to ensure that the relator "is competently performing her statutory responsibilities in a manner that comports with the provisions of the [FCA]." ${ }^{, 169}$ All the DOJ need be able to do in order to take care that the laws be faithfully executed is to intervene in the case or seek to restrain the relator's participation in the litigation - both of which the FCA authorizes expressly.

Over time, my suspicion is that the "alternative holding" of Printz will be discarded in favor of the analytic rubric of Morrison. Taken seriously, the underlying premises of the two decisions are irreconcilable. But, if there is any reed of support consistent with Morrison for the Article II rationale in Printz, it is that the administrative function at issue in Printz, although not yet prosecutorial, had the potential for turning into a criminal investigation. From that premise, and because of the scope of virtually unfettered official discretion that exists in a criminal investigation, it may have been significant in Printz that the federal executive branch simply had no way to ensure that state and local law enforcement officers were "competently performing [their] statutory responsibilities in a manner that comport[ed] with the provisions of the [Brady] Act." In other words, the Brady Act was not infirm because of some categorical constitutional requirement that the President have policy control over all government administration undertaken to serve federal interests. Rather, the Act was problematic because it gave the President no way whatsoever to make sure that those conscripted to engage in the administration of federal criminal law - in this instance, chief law enforcement officers at the state and local level - were engaged in the faithful execution of the laws.

The comparison in Riley between qui tam relators and independent counsel is unpersuasive also for two less technical reasons. Even if the control of government litigation per se is a form of executive power protected against congressional interference, it must be said that, in the real world, the accommodations of unilateral executive power in the Ethics in Government Act are operationally all but meaningless once an independent counsel is appointed. As the Whitewater/Lewinsky imbroglio dramatized, the political price entailed for a President in seeking to curtail the activity of an independent counsel is simply too steep to permit presidential management of an independent counsel. One could imagine the DOJ petitioning a court to force an independent counsel to hew to her proper jurisdiction, comply with preexisting DOJ prosecutorial policy, respect executive privilege, and so on - but the DOJ has the identical capacity to invoke judicial aid in constraining a qui tam litigator. The prospect that the DOJ would seek unilaterally to exercise its nominal discharge authority over an independent counsel without judicial imprimatur is, essentially, nil. The fact that the DOJ seems as a formal matter to have less authority over qui tam litigants is simply irrelevant to a practical comparison with independent counsel.

Moreover, any sensible weighing of the degree to which limitations on executive supervision of administration "are of such a nature that they impede $[. .$.$] the President's ability$

169. Id. 
Copyright $@ 2000$ Environmental Law Institute $®$, Washington, DC. reprinted with permission from ELR®—The Environmental Law Reporter $®$. All rights reserved.

to perform his constitutional duty," must take account of the overall significance for the President's capacity to do his job of the administrative function on which the statute impinges. What is at stake for the President in losing control over independent counsel is a loss of control over criminal investigations targeting his highest political appointees, his closest political associates, or himself. Again, it can hardly be doubted, in the wake of Whitewater/Lewinsky, that the ripple effect for executive branch functioning that this loss of control portends is profoundly serious. Even if an independent counsel investigation exonerates its target, the destabilizing effect of a prolonged criminal investigation of the sort that involves independent counsel is real.

There is no serious comparison here between the impact of independent qui tam litigation and independent criminal investigation and prosecution. A relator's pursuit of a qui tam suit that the DOJ has turned down need not engage the Executive's attention at all. These cases are of insufficient notoriety to have any public impact with regard to the credibility or effectiveness of the federal executive. If the relator prevails, the government shares in the recovery; the law has been faithfully executed. If the relator loses, it brings no discredit to the executive. Nor does it compromise the executive's resources. In the institutional life of a President, it is essentially a non-event. For this reason, too, it is not sustainable that the authority for qui tam civil litigation compromises the President's capacity to discharge his constitutional role to a greater degree than the Ethics in Government Act.

\section{Upending National Administration}

Although Riley purports diligently to implement Morrison, its analysis is more obviously congruent with Justice Scalia's categorical view in Printz that "[t]he Constitution does not leave to speculation who is to administer the laws enacted by Congress; the President, it says, 'shall take Care that the Laws be faithfully executed,' Art. II, §3, personally and through officers [appointed either by the President himself or by his principal appointees as provided in Article II, $\S 2]$." ${ }^{170}$ Under this view, it is presumably unconstitutional to transfer any responsibility for administering federal law to persons who are not subject to "meaningful Presidential control," which, in Justice Scalia's view, would ordinarily mean individuals over whom the President enjoys "the power to . . . remove."

This late in the day, it ought to be a weighty objection against this position that it would cut an astonishing swath through the myriad structures and processes by which much federal law is administered. It would plainly call into doubt the constitutionality of the so-called independent agencies, over which the President's removal power does not extend to discharge for policy disagreement. It would call into doubt the wide array of important contexts in which states "voluntarily" undertake the enforcement of federal law, often in exchange for federal funding - as they do with regard to most federal environmental law; after all, the President does not even have indirect appointment or removal authority over the state officials involved. ${ }^{171}$ It would call into doubt the very substantial administration of federal law that

170. Printz, 521 U.S. at 922 (emphasis added).

171. TrIBE, supra note 14 , at $716-17$. is undertaken by such organizationally idiosyncratic federal entities as the U.S. Postal Service (USPS).

The USPS is an interesting case, in part because it is the federal administrative entity that Americans encounter most routinely. It is run by an administrative official who has essentially no accountability to the President. The Postmaster General, who is "chief executive officer" of the USPS, is appointed by a Postal Service Board of Governors. ${ }^{172}$ Nine members of this 11-person group (all but the Postmaster General and his or her Deputy, who both serve on the board) are appointed by the President, but these members may be removed by the President "only for cause."173 This presumably means the President cannot control their appointment discretion. Moreover, it is the board, not the President, that holds statutory removal authority over the Postmaster General. ${ }^{174}$ Given the extensive responsibilities of the Postmaster General for administering federal law, this is plainly a structure irreconcilable with the Printz model of executive authority.

The problem of "voluntary" state involvement in federal law enforcement is one that Justice Scalia noted in Printz, observing only that voluntary state participation in programs of federal law enforcement allegedly provides Congress a much less powerful tool for dissipating presidential power. ${ }^{175}$ Putting aside that this is the sort of balancing judgment that his categorical analysis forbids, this is wishful thinking. It may be that the federal executive often retains formal authority under programs of voluntary state enforcement either to de-fund noncomplying states or to take over the administrative functions involved. And, yes, these remedies are typically in the hands of officials over whom the President does have some policy control. Such remedies, however, are virtually never invoked because of the political sensitivity of state-federal relationships. Equally important, it is nearly certain in such contexts that any federal agency involved in such a state-federal partnership lacks sufficient resources to undertake the law administration obligation on its own - that is why Congress created the state-federal partnership in the first place. ${ }^{176}$ The threat to hold states accountable by taking over the programs they administer "voluntarily" is essentially a bluff. Thus, if it were a constitutional command that the President have genuine policy control over all administrative activity undertaken to administer federal law, then, surely, it ought to be troubling that the President's operational control over state administrative activity undertaken to implement federal law is basically nonexistent.

Of course, repetition of a constitutional error does not amend the Constitution. If Congress has been allocating administrative authority in derogation of the constitutional design, then the breadth of its violations does not excuse them. With regard to Congress' authority over institutional design, however, the issues posed should be assessed in light of a long tradition of deferential interpretation in the face of constitutional ambiguity. Chief Justice John Marshall prefaced his analysis of the constitutionality of the national bank as follows:

172. 39 U.S.C. $\$ 202(c), 203$.

173. Id. §202(a).

174. Id. §202(c).

175. Printz, 521 U.S. at 923 n. 12.

176. Mashaw ET AL., supra note 18, at 1119. 
[A] doubtful question, one on which human reason may pause, and the human judgment be suspended, in the decision of which the great principles of liberty are not concerned, but the respective powers of those who are equally the representatives of the people, are to be adjusted; if not put at rest by the practice of the government, ought to receive a considerable impression from that practice. An exposition of the constitution, deliberately established by legislative acts . . . ought not to be lightly disregarded. ${ }^{177}$

The "doubtful question" to which Marshall was referring was the issue whether Congress had implied authority to create a corporation. The "practice of government" to which he was prepared to defer in 1819 had considerably less of a pedigree than does the practice, in 2001, of delegating administrative functions to persons whom the President does not control.

\section{Taking Accountability Seriously}

In his Morrison dissent, Justice Scalia wrote: "The purpose of the separation and equilibration of powers in general, and of the unitary Executive in particular, was not merely to assure effective government but to preserve individual freedom. $" 178$ Part of what Justice Scalia might argue in favor of his construction of Article II is that a unitary executive does implicate "the great principles of liberty," and that, therefore, de novo construction of Article II is a matter of judicial obligation.

Under Justice Scalia's constitutional vision, the major part of what a unitary executive achieves in the cause of individual freedom is political accountability. By having a single individual responsible, directly or indirectly, for all administration of federal law, the people are guaranteed, Justice Scalia supposes that the majority's political values will be reflected in the pattern of administration and that failures to administer the law faithfully can be politically redressed. As he has explained with regard to criminal prosecution:

Under our system of government, the primary check against prosecutorial abuse is a political one. The prosecutors who exercise this awesome discretion are selected and can be removed by a President, whom the people have trusted enough to elect. Moreover, when crimes are not investigated and prosecuted fairly, nonselectively, with a reasonable sense of proportion, the President pays the cost in political damage to his administration. If federal prosecutors "pick people that [they] thin[k] [they] should get, rather than cases that need to be prosecuted," if they amass many more resources against a particular prominent individual, or against a particular class of political protesters, or against members of a particular political party, than the gravity of the alleged offenses or the record of successful prosecutions seems to warrant, the unfairness will come home to roost in the Oval Office.... That result, of course, was precisely what the Founders had in mind when they provided that all executive powers would be exercised by a single Chief Executive. As Hamilton put it, "[t]he ingredients which constitute safety in the republican sense are a due dependence on the people, and a due responsibility." Federalist No. 70, p. 424. The President is directly dependent on the people,

177. McCulloch v. Maryland, 17 U.S. (4 Wheat.) 316, 401 (1819).

178. Morrison, 487 U.S. at 727 (Scalia, J., dissenting). and since there is only one President, he is responsible.
The people know whom to blame. . .

At least with regard to qui tam suits and other citizen suits to enforce civil fines, however, this description of political accountability cannot be taken seriously. To see why- that is, unless one finds the point obvious - it is helpful to move from the abstract version of political accountability that Justice Scalia invokes to a more concrete understanding of what is really at stake.

Justice Scalia's conception of accountability would seem to depend on active, knowledgeable voters. After all, unfairness, or any other defect in federal administration, will presumably "come home to roost in the Oval Office," only (1) if people are aware of the unfairness or other defect and of the Executive's capacity to act differently, and (2) if they care enough to regard these matters as salient to their voting. Presumably, the defect a voter perceives could be either of two sorts. Our hypothesized voter might want to hold the Executive to account for bad management of litigation, e.g., using disproportionate resources or making sloppy arguments in court. Or, she might want to hold the Executive to account for its values - that is, because decisions to pursue litigation or not to pursue it fail to reflect those political values that prompted the voter to support the Administration in the first place.

So, how is it that the prospect of qui tam actions or other citizen suits could undermine the capacity of such voters to hold the Executive to account? It must be recalled in this connection that the Executive is permitted with regard to all qui tam and other citizen suits for civil fines to decide whether or not to take them over. To the extent that the Executive exercises this discretion and pursues the litigation in question on its own, there is no problem in holding the Executive to account for either its management skill or its values. Hence, the accountability concern that Justice Scalia invokes relates only to those qui tam or citizen suits that the executive declines to take over-let's call them "Executive-declined suits."

If "accountability" means ensuring that defects in federal law administration "will come home to roost in the Oval Office" (or that praiseworthy federal law administration works to the President's political benefit), it is hard to see what real-world problem is caused by entrusting Executive-declined suits to private plaintiffs. One imaginable issue might be confusion. If voters mistake qui tam suits for DOJ suits and the suits are frequently unsuccessful, voters might erroneously attribute poor management decisions to the Executive, thus holding the President accountable for the wrong things. Or, if voters mistake qui tam suits for DOJ suits, whether or not they are unsuccessful, an Administration that would prefer relative laxness in law enforcement may incorrectly be perceived as favoring strong law enforcement.

But both of these scenarios seem fanciful. If we are talking about accountability for the quality of litigation management, it must be remembered that Justice Scalia has implicitly hypothesized an active, knowledgeable voter for whom the quality of litigation management is a matter of substantial interest. For such voters to mistake qui tam or citizen suits for DOJ litigation, they would have to care enough about this subject matter to know about the relevant litigation, to be able to formulate "litigation management"

179. Id. at 728-29 (emphasis added). 
Copyright $(2000$ Environmental Law Institute $®$, Washington, DC. reprinted with permission from ELR®—The Environmental Law Reporter $\circledast$. All rights reserved.

as a political issue, and to understand how the President might exercise managerial influence over DOJ suits. But, for diminished accountability through confusion to be a significant risk, these sophisticated voters would also have to be ignorant enough of actual litigation that they would not understand that qui tam litigation and citizen suits are controlled by private parties. It is a good guess, I suggest, that this is a null set of voters. Any worldly voter knowledgeable enough about litigation management to regard this as a politically salient issue will know the difference between private suits and government-initiated suits.

For voters concerned about Administration values, however, the problem may seem more genuine. There may be voters who do not want the Administration to be aggressive with regard to a particular area of law enforcement, who do not know much about the logistics of litigation, and who are confused when they see headlines about particular defendants being forced to pay civil fines with regard to that area of regulated activity. They may believe that the Administration they wanted to be lax in environmental enforcement is, in fact, being aggressive and may thus hold the President accountable for a lapse in political fidelity that never really happened. Alternatively, there may be voters who want an Administration to be aggressive in law enforcement, who mistake successful qui tam litigation for successful DOJ action, and who thus attribute to the Administration a commitment to an area of law enforcement that may not exist. If the Administration is not really committed to that area of law enforcement, then the credit the confused voter gives to the President for a qui tam victory is unearned.

But this, too, is all pretty unreal. It is implausible that qui tam or citizen suits, even if mistaken for executive branch initiatives, would make more than a marginal impact on the overall record of law enforcement in a particular Administration. As it is, there is no such thing as an Administration so deregulatory that it never enforces the law, nor an Administration so aggressive that it prosecutes every conceivable law violation. Yet, this does not confuse the voters about an Administration's values. Any Administration's overall political stance as pro- or anti-regulation, as manifested in a wide range of administrative activity, is likely to be far more evident than any one lawsuit or even any one sub-program of litigation. To take an obvious example, even if voters under the Reagan or Bush Administrations mistook a privately steered qui tam suit for a DOJ suit, they would be unlikely to mistake either Administration's overall deregulatory stance on the environment. Presidential budgeting decisions and a President's support or lack of it for various items of proposed legislation, for potential regulations, and for litigation that remains within federal control will surely paint a pretty clear picture of where an Administration's sentiments lay. There seems no genuine likelihood that the existence of qui tam litigation can so confuse voters about the chain of command in such lawsuits as to prompt misunderstandings of a President's political value commitments.

But perhaps these examples do not quite capture what Justice Scalia is after. Even though Justice Scalia refers to presidential responsibility as a matter of "[t]he people know[ing] whom to blame," maybe that's not really his point. Perhaps we ought not really care whether decisions regarding federal litigation "come home to roost in the Oval Office." A more compelling version of his central point may be that, even if the people know nothing about the chain of command with regard to various forms of litigation, they do know whom they elected as President and why. They trust the President or have, at least, entrusted him. The reason the President should have plenary control over all litigation in pursuit of federal interests is because it is a more democratic system even if no one actually holds the President accountable for his performance in this regard. At least, an elected President empowered under the Scalia vision of the Constitution would have the opportunity to manage all litigation on behalf of the interests of the United States, even if no one is likely to hold him accountable for how it is done. Whether or not he is exercising such opportunities and whether voters know anything about the President's involvement in such matters is beside the point. We get to vote for Presidents, but not for qui tam plaintiffs; we are thus better off in democratic terms if the President gets to control public litigation.

This is a less frivolous case, of course, because it does not rely on an incoherent hypothesis of active, knowledgeable, but deeply confused voters. It depends only upon the fact of presidential elections. The problem, however, is that this vision of accountability offers a doubly incomplete version of democracy. First, it misperceives qui tam litigation and citizen suits exclusively as constraints upon executive discretion in law enforcement. In fact, qui tam litigation and similar citizen suits actually give the executive additional law enforcement options. The executive may decide that an enforcement action is not worth filing given its own limited resources, but rather that the matter would be worth pursuing if the prospect of potential reward should be enough to entice a private plaintiff - without cost to the government - to take the risk of suing in the hope of recovering a bounty or, at least, attorneys fees. In such cases, a private plaintiff's decision to go forward is consistent with the Executive's agenda, even if the Executive cannot entirely control the suit. Thus, qui tam statutes actually give the President an additional mechanism for fulfilling his obligation of democratic responsiveness, which may itself outweigh any real-world problem caused for democratic accountability by Executive-declined suits that an Administration actually opposes in principle.

Second, and more fundamentally, the people elect not only the President; they also elect Congresses, including those Congresses that enacted the laws that qui tam and citizen suits seek to enforce. Where qui tam and citizen suits go forward successfully under private plaintiffs, we are thus getting the fuller benefit of the votes we cast for the legislative branch. This also does not undermine democratic accountability; it advances it.

The only citizen suits that are truly problematic from a democratic point of view are those cases (1) that the executive would prefer not to go forward because they are unlikely to succeed (and thus are faithful neither to Congress's aims, nor the President's), (2) that the executive would stop if it had the unilateral power to do so, but (3) that go forward anyway-and unsuccessfully so-because the plaintiffs have made an incorrect assessment that they were likely enough to prevail to justify the economic burden of litigation. In lawsuits it suspects are within this category, the executive, of course, retains the capacity either to intervene or to inform the trial court of its views. But there remains at least some theoretical prospect that such a nonmeritorious suit, whose lack of merit the Executive has brought to a court's attention, will nonetheless still go forward because 
the court remains unpersuaded and because the Executive cannot unilaterally halt the litigation. This prospect, however, represents an awfully thin tear in the fabric of democratic accountability. For all we know, the Executive would have as much success invoking a court's aid in curbing an insubstantial qui tam suit as it would in monitoring and disciplining those assistant U.S. attorneys who overzealously bring ill-advised anti-fraud or environmental protection suits on behalf of the federal government. And, with all respect to Justice Scalia, there seems to be no evidence whatever that the founding generation ever identified, much less worried about the remote likelihood of the example I have sketched.

\section{Taking History Seriously}

This last observation brings us back to Justice Stevens' point in Vermont Agency. Namely, it ought to be determinative, especially for an avowed textualist such as Justice Scalia, that the people who wrote Article II plainly did not understand their text as commanding his result. Evidence abounds that the founding generation did not equate the vesting of executive power in a President or governor with the chief Executive's policy control over all administration. ${ }^{180}$ Not the least of such evidence is, of course, that the early Congresses enacted numerous informer and qui tam statutes. ${ }^{18 P}$ That is precisely the basis on which Justice Scalia found that modern qui tam laws cannot be found violative of Article III. ${ }^{182}$

In assessing the plausibility of the Scalia thesis, it is worth remembering the familiar facts that neither the original U.S. Department of Treasury, nor the U.S. Post Office was understood to be under presidential control to the same degree as the U.S. Departments of War and of Foreign Affairs. ${ }^{83}$ The Treasury Department's organic act does not mention the President, and, for a significant period, the Treasury Department submitted budget estimates and tax recommendations to Congress without presidential review. ${ }^{184}$ This does not suggest a tightly controlled, hierarchical view of inherent executive power.

Criminal prosecution was clearly not perceived as an inherently executive task. Even in several new states whose constitutions included express separation-of-powers requirements, attorneys general were nonetheless appointed by legislatures, and prosecutors were appointed by courts. ${ }^{185}$ According to Dean Abraham Goldstein: "In the early years of the Republic, the prosecuting attorney was a minor judicial official." 186 Federal prosecutors were not for-

180. See generally Gerhard CASPer, SeParating Power: Essays on the Founding Period (1997); Martin S. Flaherty, The Most Dangerous Branch, 105 YALE L.J. 1725 (1996); William B. Gwyn, The Indeterminacy of the Separation of Powers and the Federal Courts, 57 Geo. Wash. L. Rev. 474 (1989); Peter M. Shane, Independent Policymaking and Presidential Power: A Constitutional Analysis, 57 Geo. Wash. L. Rev. 596 (1989); William B. Gwyn, The Indeterminacy of the Separation of Powers in the Age of the Framers, 30 WM. \& MARY L. Rev. 263 (1989).

181. Riley v. St. Luke's Episcopal Hosp., 196 F.3d 514, 545-48 (5th Cir. 1999) (Stewart, J., dissenting).

182. Vermont Agency, 120 S. Ct. at 1865, 30 ELR at 20624.

183. Shane, supra note 180 , at $615-16$.

184. TRIBE, supra note 14, at 713-14.

185. Shane, supra note 180, at 603-06.

186. Cited in Tribe, supra note 14, at 697 n.108. mally brought within a central DOJ until 1870 . As described by Professor Tribe: "Even though Congress ultimately chose to provide for [U.S. Attorney] appointment by the President with Senate confirmation, 'the original part-time, fee-for service federal prosecutors remained virtually autonomous." "187 As late as 1831, President Jackson felt compelled to seek a formal Attorney General's opinion to legitimate his direction to a federal district attorney to discontinue the prosecution of an action to condemn certain jewels that had been stolen from the royal family of the Netherlands and then brought unlawfully into the United States. ${ }^{188}$ If Justice Scalia's view of executive power were widespread in 1787, this would hardly have seemed an open question over 40 years later, especially in an area of foreign policy sensitivity.

In fact, it is noteworthy that the sources of doubt cited by Chief Justice Marshall with regard to the chartering of a national bank did not include a separation-of-powers objection. Congress entrusted significant administrative functions, such as the receipt and disbursement of public funds, the issuance of notes payable on demand, and the location of "offices of discount and deposit" " the national bank, four-fifths of whom were elected by private shareholders. ${ }^{190}$ The President controlled none of these. Congress further authorized the corporation governed by these directors to "sue and be sued."191 Yet, it does not appear that anyone argued against the bank that it removed the administration of federal law from presidential control or empowered persons not within his control to sue on behalf of the interests of the United States.

This evidence confirms that the executive power invested by Article II cannot reasonably be understood to entail presidential policy control over all administration of federal laws. The President's duty to take care that the laws be faithfully executed is chiefly a charge to see that Congress' enactments are diligently put into force, according to their terms, by the persons delegated with the responsibility to do so. With regard to qui tam litigation and citizen suits generally, the President is responsible to oversee decisions by federal agencies either to take charge of such suits or to permit them to go forward at private initiative. He may also supervise decisions whether to intervene in such suits that do go forward or to permit them to proceed without federal participation, to be sure such decisions are made soundly and in accord with the law. Once these functions are performed, however, the President's duty and constitutional prerogative are at an end.

The historically conclusive arguments in favor of the constitutionality of qui tam litigation under Article II also sustain citizen suits in which the plaintiff is not a formal qui tam relator, but in which the direct beneficiary of the remedy, if achieved, is nonetheless the United States. In such cases, ex-

187. $I d$. at 697 (citation omitted).

188. The Jewels of the Princess of Orange, 2 Op. A.G. 482 (1831), excerpted in Peter M. Shane \& Harold H. Bruff, Separation of Powers Law: Cases and Materials $466(1996)$. The opinion is excerpted also, with historical commentary, in H. JEFFERSON Powell, The Constitution and the Attorneys General 50-58 (1999).

189. Act of April 10, 1816, §10, para. 14, 3 Stat. 296, 273.

190. Id. $\S 8,3$ Stat. at 269-70.

191. Id. §7, 3 Stat. at 269. 
Copyright $@ 2000$ Environmental Law Institute $®$, Washington, DC. reprinted with permission from ELR®—The Environmental Law Reporter $®$. All rights reserved.

emplified by Steel Co. ${ }^{192}$ and Laidlaw, ${ }^{193}$ the United States stands in essentially the same relationship to the litigation as in qui tam actions. That is, before a citizen may file suit, the relevant statutes provide that the United States must be notified and given the opportunity to pursue the litigation itself. Should the citizen suit proceed, the United States may intervene as of right. So long as there is a judicial avenue to pursue, the executive branch has recourse to seek to assure that citizen plaintiffs are competently performing their statutory responsibilities in a manner that comports with the relevant law. The executive is thus enabled to take care that the laws implicated in these suits are being faithfully executed. That is all that the Constitution requires.

\section{Conclusion}

Justice Scalia's doubts, only partially resolved, about the permissibility of qui tam litigation and citizen suits under Article II and Article III both proceed from his theory of executive power. He believes Article II invests in the President all power to administer the laws enacted by Congress, whether by the President himself, by his appointees, or by persons who are accountable to his appointees. Justice Scalia's theory of standing is grounded in the notion that Article III limits on judicial power are significantly designed to keep courts from intruding upon this very executive power. In the face of historical evidence, Justice Scalia has relented, at least on the Article III point, with regard to qui tam litigation. He remains opposed, however, to similarly constructed citizen suits, and, even for qui tam litigation, the Article II question remains alive for him.

This approach is wrong-headed and more than a little ironic. The Spirit of the Laws, ${ }^{194}$ published by Baron de Montesquieu in $1748,{ }^{195}$ popularized the delineation of government powers as executive, legislative, and judicial. ${ }^{196}$ Previously, it had been common to regard judicial power as embraced within the executive "magisterial" power. This was the prevailing popular view in the American colonies; the first state constitutions after independence did not create the judiciaries as separate branches, but subjected them to legislative control as part of a general program of subordinating much-distrusted executive magistrates to newly empowered state legislatures. ${ }^{197}$ It turned out, of course, that unchecked legislative power had a capacity for abuse every bit as tyrannical as unchecked executive power. ${ }^{198}$ It was thus the disappointing experiences of arbitrary government in the newly independent colonies of the late 1770s and 1780 s that stoked popular interest in a more robust view of separation of powers, a version in which the judiciary had co-equal status with the executive and the legislative branches. ${ }^{199}$ This was a substantial transformation in Amer-

192. See supra notes $97-106$ and accompanying text.

193. See supra notes 114-22 and accompanying text.

194. Baron de Montesquieu, The Spirit of the Laws ix, xii (T. Nugent trans., Hafner Press 1949) (1748) [hereinafter SPIRIT OF THE LAWS].

195. Franz Neuman, Introduction to SPIRIT OF THE LAWS, supra note 194.

196. Id. at ix.

197. Gordon S. Wood, The Creation of the American Republic, 1776-1787, at 454 (1969).

198. Id. at 403-09.

199. Id. at 454 . ican separation-of-powers thinking. In the words of historian Gordon Wood: "The Department which benefited most from the new, enlarged definition of separation of powers (that evolved during the 1780s) was the judiciary."200

The move to an independent judiciary, however, was by no means a repudiation of the wisdom of separating it from the executive branch. It was precisely because checking the executive retained its importance that the Framers, rather than reuniting the different aspects of the magisterial power, reacted to the experience of legislative abuse by following Montesquieu and locating the courts in an independent branch. It would turn Montesquieu on his head to argue that the judiciary was rendered independent from both legislature and executive in order to make the executive stronger. Montesquieu advocated separating the judicial power from the magisterial in order to subject the sovereign more effectively to the rule of law, ${ }^{201}$ and it was to a rule of law version of the separation of powers that the Framers were committed. The fact that rule of law concerns were no longer focused exclusively on the imperative of controlling a potentially arbitrary magistracy does not mean that executive discretion was to be wholly unleashed. It would be perverse to regard the Framers' redoubled commitment to the rule of law, embodied in the newly designed independent federal judiciary, as a tool for preserving executive discretion.

It similarly misreads the Faithful Execution Clause to treat it as a significant vesting of power in the President. It is chiefly a form of protection for legislative power. Its phrasing descends from the English Bill of Rights, through the Virginia Constitution, and was intended most importantly to forbid the executive's suspension of statutes. ${ }^{202}$ To read into the Faithful Execution Clause a limitation on congressional authority is to turn a legislative shield into an executive sword. Authorizing private rights of action to bolster the enforcement of the laws is totally consistent with Faithful Execution Clause values.

Standing law is better understood as an effort to protect judicial power. As argued earlier, it would weaken the judiciary vis-à-vis the other branches for courts to render merely advisory opinions or judgments in suits that are factually underdeveloped, or in suits in which the judicial determination could be administratively altered. Giving a judicial imprimatur to collusive suits would represent an abandonment of the court's public dispute resolution function altogether. It is to protect only against these important, but limited concerns that standing rules ought to be fashioned and followed. The work of keeping the judiciary out of the business of the other branches is a separate matter, and handled amply through the political question doctrine and rules on justiciability.

As for Article II, the vesting of executive power in a President is best understood as ousting the legislature from its own direct involvement in administering the

200. Id. at 453-54.

201. William B. Gwyn, The Meaning of the Separation of Powers: An Analysis of the Doctrine From Its Origin to the Adoption of the United States Constitution 106-08 (1965).

202. Peter M. Shane, Separation of Powers and the Rule of Law: The Virtues of "Seeing the Trees," 30 WM. \& MARY L. Rev. 375, 380 (1989); Peter M. Shane, Presidents, Pardons, and Prosecutors: Legal Accountability and the Separation of Powers, 11 YALE L. \& Pol'y Rev. 361, 393-94 (1993). 
Copyright $@ 2000$ Environmental Law Institute $®$, Washington, DC. reprinted with permission from ELR®—The Environmental Law Reporter $®$. All rights reserved.

laws, ${ }^{203}$ and in rendering the President accountable for the discharge of those powers that Article II proceeds to confer, explicitly or implicitly. These did not include in 1787 , just as they do not include now, the power of policy supervision over all administration of federal law. So long as Congress does not usurp administrative authority itself, it may attenuate the President's policy control over federal law enforcement, so long as it leaves intact his capacity to discharge his Article II functions.

Properly construed, the Constitution poses no structural obstacles to Congress' decisions to authorize privately initiated lawsuits to enforce public norms. These have become a conventional form of federal litigation. Confining such suits to a structure that looks like a conventional suit in tort or contract is to impose private-law forms on public-law purposes, and for no good reason - certainly none that is rooted in the Constitution.

Of course, whether citizen suits or qui tam litigation provide appropriate avenues for law enforcement is a question

203. The rule against Congress' aggrandizement of its administrative role is firmly embedded in such cases as Myers v. United States, 272 U.S. 52 (1926) (Congress may not reserve authority to the Senate to confirm removals from office of presidential appointees); Buckley v. Valeo, 424 U.S. 1 (1976) (Congress may not provide for its own appointment of "officers of the United States," but is confined when authorizing the appointment of such officers to those methods enumerated in Article II of the Constitution); INS v. Chadha, 462 U.S. 919 (1983) (Congress may not nullify a prior delegation of administrative authority except through a statute enacted by both Houses and presented to the President for signature or veto); and Bowsher v. Synar, 478 U.S. 714 (1986) (Congress may not provide for legislative branch participation in the removal of an officer of the United States except through impeachment). of policy that a sensible Congress must address. As a matter of policy, there is a lot to be said for entrusting law enforcement chiefly to the federal executive branch, under the watchful coordination of a single Attorney General. The DOJ is surely prepared to make that argument to Congress, although it is important to note that the executive branch has itself defended the constitutionality of qui tam litigation. ${ }^{204}$ Once that argument is considered, however, it is up to Congress to decide whether authorizing citizens to pursue civil fines on behalf of the federal government is a salutary aid to the faithful execution of the laws. The choice of remedies is within Congress' discretion.

This does not mean that courts should automatically entertain every piece of litigation that is presented as a citizen suit. A citizen suit plaintiff still needs a cause of action, a legal right to sue. In some cases, the courts may infer such rights directly from the Constitution. In the overwhelming majority of cases, however, this will be a matter of statutory interpretation. If no right of action exists, then a citizen suit cannot proceed. On the other hand, if Congress has authorized the suit, then-so long as the dispute is presented in an adversarial context and in a form historically viewed as capable of judicial resolution-Article III has been satisfied. And there is no Article II barrier to going forward because no inherently presidential power is compromised by such litigation.

204. Brief for United States as Amicus Curiae, Vermont Agency of Natural Resources v. United States ex rel. Stevens, 120 S. Ct. 1858, 30 ELR 20622 (2000) (No. 98-1828) (1999 WL 1076137). 